This is the peer reviewed version of the following article Garratt, E. A., Chandola, T., Purdam, K. and Wood, A. M. (2017), Income and Social Rank Influence UK Children's Behavioral Problems: A Longitudinal Analysis. Child Dev, 88: 1302-1320, which has been published in final form at https://doi.org/10.1111/cdev.12649. This article may be used for noncommercial purposes in accordance With Wiley Terms and Conditions for selfarchiving. 
Income and Social Rank Influence UK Children's Behavioral Problems: A Longitudinal Analysis

Full reference: Garratt, E., Chandola, T., Purdam, K., \& Wood, A.M., (in press). Income and Social Rank Influence UK Children's Behavioral Problems: A Longitudinal Analysis. Child Development.

Final submitted pre-proof version; the copyright and copy of record reside with the journal. Accepted by Child Development published by Wiley-Blackwell. 


\begin{abstract}
Children living in low-income households face elevated risks of behavioral problems, but the impact of absolute and relative income to this risk remain unexplored. Using UK Millennium Cohort Study data, longitudinal associations between Strengths and Difficulties questionnaire scores and absolute household income, distance from the regional median and mean income, and regional income rank were examined in 3-12 year-olds $(n=16,532)$. Higher absolute household incomes were associated with lower behavioral problems, while higher income rank was associated with lower behavioral problems only at the highest absolute incomes. Higher absolute household incomes were associated with lower behavioral problems among children in working households, indicating compounding effects of income and socioeconomic advantages. Both absolute and relative incomes therefore appear to influence behavioral problems.
\end{abstract}

Keywords: Mental health, Relative Rank, Social Status 


\section{Income and social rank influence UK children's behavioral problems:}

\section{A longitudinal analysis}

There exists a clear negative association between household income and children's behavioral problems, in which children living in lower-income households have a higher risk of behavioral problems than their more economically advantaged peers. Mounting evidence suggests that associations between low incomes and adults' impaired mental health might reflect the role of relative - not absolute - income, but the potential relevance of relative income to children's behavioral problems has never been considered. The negative consequences of childhood behavioral problems both for children's current quality of life (Bastiaansen, Koot, Ferdinand, \& Verhulst, 2004), and adult outcomes including education (Delaney \& Smith, 2015), mental health (Kim-Cohen et al., 2003), and unemployment (Egan, Daly, \& Delaney, 2015) make it important to understand the mechanism underlying these associations. Addressing the negative consequences of low incomes on children's behavioral problems could therefore have positive and wide-reaching implications.

\section{Income and physical and mental health in adults and children}

The negative association between absolute household income and children's behavioral problems is well established. In 2004, 7.2\% of 5-10 year-old UK children had a mental disorder, and mental disorders were over twice as prevalent in children living in the lowest- than the highest-income households (12.3\% and 4.5\%) (Green, McGinnity, Meltzer, Ford, \& Goodman, 2005). This pattern replicates evidence from adolescents (McLaughlin, Costello, Leblanc, Sampson, \& Kessler, 2012) and adults (Lorant et al., 2003).

\section{Income and behavioral problems: Absolute or relative income?}

The negative association between household income and children's behavioral problems could reflect the importance of material resources (absolute household income) or the symbolic meaning of income as a measure of status (relative household income, or a 
person's income position in relation to others'). Living in a low-income household might result in material deprivation, with negative consequences for children's behavioral problems. Alternatively, the effect of lower relative incomes might operate through experiences of stress, where both self-reported (Attar, Guerra, \& Tolan, 1994) and biologically-assessed stress (Kryski, Smith, Sheikh, Singh, \& Hayden, 2013) are higher among children living in low-income households.

Although debates are ongoing, increasing evidence suggests that associations between income and adults' mental health reflect relative income, which captures income position based on individuals' actual income (Kuo \& Chiang, 2013). These objective measures of relative income are distinct from those of subjective social status, which capture people's assessments of their perceived social position but may not correspond to their actual incomes. Evidence for associations between income inequality and aggregate-level mental health outcomes further strengthen the suggestion that the income distribution is relevant to adults' mental health (Pickett, James, \& Wilkinson, 2006), and further suggest that the objective income distribution is important to mental health, independent of any subjective appraisals of social position.

Despite evidence that associations between low incomes and impaired mental health in adults might reflect the role of relative income, the possibility that associations between low incomes and higher behavioral problems in children are also influenced by relative income has never previously been explored empirically. This is an important omission because associations between low incomes and adults' mental health and children's behavioral problems - in particular, the income or status comparisons proposed by relative income accounts - might be determined differently in adults and children. While the accuracy of status judgments does improve with age (Tudor, 1971), 6-12 year-old children's judgments of their own status correspond to those of their peers (Malloy, Albright, \& Scarpati, 2007). 
These abilities to perceive social differences may be rooted in early childhood development, as 16-month-old infants are observed to look significantly longer at fair than unfair distributions of toys (Geraci \& Surian, 2011). It is alternatively possible that associations between income and children's behavioral problems do not reflect children's own experiences of social stratification but the indirect experiences of their parents. Relative incomes influence mental health through experiences of stress, and low incomes are consistently associated with higher levels of stressful experiences (Attar et al., 1994) and biological stress markers (Kryski et al., 2013) in both adults and children. Evidence for stress contagion - where observing another person's stressful experiences can itself provoke a biological stress response - in infants demonstrates that children can experience the consequences of their parents' stress (Wethingon, 2000), thereby offering a pathway through which objectively defined relative incomes might relate indirectly to children's behavioral problems.

In support of the role of relative income on children's outcomes, two studies have reported associations between higher relative household incomes and better physical health among infants (Lhila \& Simon, 2010; Reagan, Salsberry, \& Olsen, 2007). Likewise, US children's behavioral problems were associated with state-level income inequality but not with state-level average absolute household income (Pickett \& Wilkinson, 2007), and income inequality was associated with performance on the UNICEF child well-being index in 21 countries (Pickett \& Wilkinson, 2015), collectively suggesting that the income distribution or relative income - might be relevant to children's behavioral problems.

\section{Relative income: What is the mechanism?}

Despite significant efforts, past research has not reached a consensus over the exact nature of the individual-level relative income measures that might underpin associations between income, adults' mental health and children's behavioral problems. Several theories 
have been proposed: The reference income hypothesis states that the economic resource gap between people is important, so both the number of richer people and the size of income discrepancy (distance from the 'average' person) is relevant. This measure has been conceptualized as both the distance from the median or mean income of a specified comparison group (Clark, Masclet, \& Villeval, 2008), and using the Yitzhaki index, which captures the difference between each person's income and the higher-income members of their comparison group, divided by the size of comparison group (Yitzhaki, 1979). In contrast, the income rank hypothesis (C. J. Boyce, Brown, \& Moore, 2010) is founded on research from evolutionary psychology and cognitive science and states that people's ordinal rank position in the income distribution influences their mental health.

The income rank hypothesis states that cognitive rank-based income or status comparisons result in social defeat among low-ranking group members. The evolutionary component is based on evidence from primate studies, where low-ranking animals display appeasement behaviors termed 'involuntary defeat syndrome' (IDS) following social defeat. In humans, income-based status comparisons resemble objective rank-based comparisons that determine status in non-human primates, so low incomes are hypothesized to trigger the IDS response. These appeasement behaviors demonstrate the absence of threat, withdrawal and disengagement through displays of submission and shame, comprising gaze aversion, constricted posture and downwards head movements. These displays are observed in adults (Keltner, Young, \& Buswell, 1997), children (Belsky, Domitrovich, \& Crnic, 1997), and nonhuman primates (Shively, Laber-Laird, \& Anton, 2000). While these behaviors were adaptive in our group-living past by discouraging physical aggression from higher-ranking group members (Taylor, Gooding, Wood, \& Tarrier, 2011), in contemporary society they can be maladaptive as feelings of being devalued and defeated are stressful to both adults (Dickerson \& Kemeny, 2004) and children (Lewis \& Ramsay, 2002). Defeat and entrapment are also 
associated with anxiety problems, depression, posttraumatic stress disorder and suicidality (Griffiths, Wood, Maltby, Taylor, \& Tai, 2014; Siddaway, Taylor, Wood, \& Schulz, 2015). Collectively this suggests that the negative association between income and health outcomes could result from rank-based status comparisons that prompt feelings of inferiority and defeat.

In parallel, the cognitive component of rank theory provides evidence suggesting that people are sensitive to rank position. It is less cognitively demanding to make sequential comparisons between a person's own income position and every other person's income and remember the number of stimuli higher than their own - capturing their rank position - than to calculate distance from the median or mean. If people naturally make judgments based on rank, then associations between relative income and mental health are more likely to reflect rank-based ordinal comparisons than more demanding calculations of distance from the 'average' (median or mean) person. This is particularly relevant in crowded parts of the income distribution, where people's incomes are similar and the differences between incomes are small, so evaluating distance from the median or mean may be especially challenging. In contrast, the difficulty of making ordinal rank-based comparisons is independent of the characteristics of the income distribution. Evidence supporting the cognitive basis of rank theory has been reported using a laboratory paradigm in which the rank position of stimuli is manipulated in two conditions while maintaining equal range and distance from the mean. Any differences between the judgments of common points therefore suggest a sensitivity to rank position. Laboratory studies have identified rank-based judgments including in relation to wage satisfaction (Brown, Gardner, Oswald, \& Qian, 2008), gratitude (Wood, Brown, \& Maltby, 2011), , mental health symptoms (Melrose, Brown, \& Wood, 2013), personality (Wood, Brown, Maltby, \& Watkinson, 2012), and the healthiness of foods (Aldrovandi, Brown, \& Wood, 2015). In parallel, analyses of survey data further suggest that rank-based 
comparisons are naturally used outside of laboratory conditions for the outcomes of life satisfaction (C. J. Boyce et al., 2010), workplace satisfaction (Brown et al., 2008), and physical health (Daly, Boyce, \& Wood, 2015; Hounkpatin, Wood, \& Dunn, 2016). The activation of brain regions in response to the rank size of stimuli also implies that sensitivity to social rank is a general cognitive capacity, reinforcing the cognitive basis of rank theory (Mullett \& Tunney, 2013). Recent research on adults indicates that low income rank but not low reference incomes are associated with higher psychological distress (Wood, Boyce, Moore, \& Brown, 2012), greater depressive symptoms (Hounkpatin, Wood, Brown, \& Dunn, 2015), and higher risks of suicidal thoughts and suicide attempts (Wetherall, Daly, Robb, Wood, \& O'Connor, 2015), independent of absolute household income. Associations between income rank and allostatic load (capturing over-exposure to stress) further suggest that income rank - not absolute income - relates to stress (Daly et al., 2015; Hounkpatin et al., 2016). Despite this persuasive evidence from adults, it cannot be assumed that children's wellbeing is influenced by the same mechanisms as those operating in adults, and these mechanisms have never been explored in children. Nonetheless, associations between rank position and behavioral manifestations of distress in non-human primates suggest that sensitivity to rank may be a general cognitive capacity, so might be expected in children. Only one study has examined rank theory in a younger population: Elgar, De Clercq, et al. (2013) reported that in cross-sectional analyses, lower affluence rank was associated with a larger number of psychosomatic symptoms in adolescents, and interaction effects demonstrated that affluence rank was more closely associated with psychosomatic symptoms at low levels of affluence. In the current study, examining the comparative strength of income rank and distance from the median and mean will therefore explore whether children are more sensitive to income rank, or whether the size of income differences is more important to 
children's behavioral problems. This will also inform the broader question of whether income relates to children's behavioral problems through absolute or relative income pathways.

\section{The role of multiple socioeconomic disadvantages on children's behavioral problems}

A related question is whether the negative association between income and children's behavioral problems reflects the consequences of multiple socioeconomic disadvantages. According to the cumulative risk model, children experiencing socioeconomic disadvantages - such as their parents not working or having low educational qualifications - alongside low absolute household incomes may face particular risks of behavioral problems. Understanding how multiple socioeconomic disadvantages relate to children's behavioral problems is therefore vital for informing policies to target children who suffer most as a result of low incomes.

\section{The role of income on different behavioral dimensions}

The role of household income on children's behavioral problems may also vary between behavioral dimensions. Past research suggests that household socioeconomic status (based on parents' income and education) relates more closely to children's externalizing than internalizing behaviors (Amone-P'Olak et al., 2009; Bøe, Øverland, Lundervold, \& Hysing, 2012; W. T. Boyce et al., 2012). On the other hand, existing research on the role of relative income to adults' mental health has been largely confined to internalizing dimensions, raising the possibility that externalizing and internalizing behaviors might have specific associations with absolute and relative incomes. This possibility has not previously been explored and therefore warrants attention.

\section{The current study}

We considered three research questions:

1. Are absolute and relative household incomes associated with behavioral problems in 3-12 year-old children? 
2. Are multiple socioeconomic disadvantages more closely associated with children's behavioral problems than socioeconomic disadvantage on one measure only?

3. Are absolute and relative household incomes equally associated with children's internalizing and externalizing behaviors?

We hypothesized that (1) children's behavioral problems would relate more closely to objectively defined relative incomes - specifically income rank - than absolute household income, even after adjusting for absolute household income; (2) Consistent with the cumulative risk model, children living in households with both low absolute household income and other socioeconomic disadvantages will have higher behavioral problems than children experiencing low absolute household incomes only. Specifically, children living in households with both low absolute and low relative incomes (or other measures of socioeconomic disadvantage) will have more severe behavioral problems than children living only in low absolute income households, while relative incomes will be less relevant to behavioral problems among children living in higher absolute income households; (3) Absolute and relative household incomes will relate more closely to children's externalizing than internalizing behaviors.

\section{Method}

\section{Data and participants.}

We used data from the UK Millennium Cohort Study (MCS). The MCS is a multidisciplinary study examining the lives of 19,941 children born in the UK in 2000-02. Children's mothers and her partner (if applicable) were interviewed to provide information about the child, their parents and the household. Data are available from 9 months (2000), 3 years (2003), 6 years (2006), 8 years (2008) and 12 years (2012). We used data from waves 2-5, when children were 3-12 years old (see Table 1). The sample design incorporates stratification and clustering to over-represent wards in disadvantaged areas, the smaller 
countries of the UK and English wards with high ethnic minority populations, and can be adjusted in analyses to provide a nationally representative sample of UK children. We excluded children whose parents had 'other' educational qualifications $(n=661,1.2 \%)$ as this captures overseas qualifications held by migrants, who are not the focus of this study. Sensitivity analyses confirmed that our results were unaffected by this exclusion. Multiple births were also excluded $(n=537)$.

Throughout the study, $11.9 \%$ of households provided no income data either by refusing or by not knowing their income. The data holder, the Centre for Longitudinal Studies, imputed missing data using interval regression based on the covariates of age, housing tenure, labor market status, stratum, region, benefit receipt, ethnicity, education, accommodation type, number of children and family type. Children with missing covariate data were ascribed the characteristics reported in previous waves. Cases with missing data on behavioral problems were removed from analysis. Missing data reduced the analytic sample by $5.5 \%$ to 52,956 observations from 16,532 children who were included in the sample in wave $2(n=13,887)$, wave $3(n=14,093)$, wave $4(n=12,775)$ and wave $5(n=12,201)$. Overall, 9,046 children $(54.7 \%)$ were present in all four waves. A previous examination of nonresponse concluded that respondents and non-respondents were comparable (Plewis, 2007). Characteristics of the MCS sample are shown in Table 1.

\section{Measures}

\section{Absolute household income.}

Absolute household income $A_{i}$ was calculated as total household income from all sources after tax and before housing costs. It was adjusted for family size and composition using the modified OECD equivalence scales, which grant the first adult a value of 0.67 , subsequent adults and children aged $14-18$ a value of 0.33 , and children below 14 years a value of 0.20 . Equivalized income is derived by dividing total household income by the 
equivalization factor to best operationalize the family's material resources. This was available as a derived variable. Following standard practice, absolute household income was then log transformed to reduce skew, then standardized between 0 and 1 .

\section{Income rank.}

Income rank was calculated using untransformed equivalized household income within the household's region of UK residence (North East, North West, Yorkshire and the Humber, East Midlands, West Midlands, East of England, London, South East, South West, Wales, Scotland, Northern Ireland). Regional income comparisons account for geographical differences in incomes and living costs, while capturing the influence of similar individuals who form the basis of social interactions. Regional reference groups have been used previously to examine relative incomes and mental health in adults (eg: Wood, Boyce, et al., 2012) and adolescents (Elgar, De Clercq, et al., 2013), and a comparison of reference groups reported that relative income was more closely associated with adults' overall health when calculated within regions than other potential comparison groups (Hounkpatin et al., 2016). Income rank $R_{i}$ captures the income position $P_{i}$ of child $i$ divided by the size of comparison group $n$ to identify the proportion of lower-ranking children (Brown et al., 2008):

$R_{i}=\frac{P_{i}-1}{n-1}$

Untransformed income was used, although the log transformation makes no difference to values of income rank. Income rank was normalized between 0 and 1 to control for region size, where higher ranks indicate higher incomes. The same absolute household income produces a different rank position depending on the regional income distribution. Income rank was calculated from equivalized household income for direct comparability with absolute household income.

While comparison groups such as schools might be considered relevant, this was not possible because children had not reached school age at the start of the survey, and in the 
later waves school information was not available for all children. Collectively these issues serve to reduce the sample size for school-based analysis and could introduce bias.

\section{Reference income.}

We conceptualized reference incomes as distance from the regional mean income. This measure has been widely used previously (Clark et al., 2008) and is conceptually similar but methodologically simpler than the Yitzhaki specification. As a robustness check, all models were also estimated using Yitzhaki income and all results were replicated (see supplementary analyses). Distance from the mean (DFM) $C_{i}$ was defined as the distance between each household's total untransformed equivalized absolute household income $A_{i}$ and the mean income of their regional comparison group $u$, to capture income comparisons against the 'typical' group member:

$$
C_{i}=A_{i}-\bar{u}
$$

DFM was normalized between 0 and 1 , where incomes higher than the mean translate to positive values and a greater income surplus, while incomes below the mean produce negative values and a greater income shortfall. The same absolute household income produces a different value of DFM depending on the regional income distribution. DFM was calculated from equivalized household income for direct comparability with absolute household income. Untransformed income was used, although the log transformation makes no difference to values of DFM.

While distance from the median might be considered more suitable because the median is less subject to skew from extremely high values than the mean, the normalization transformation makes values of distance from the median identical to those from DFM. We report results for DFM, although identical results are obtained using distance from the median. 


\section{Strengths and Difficulties Questionnaire.}

Children's behavioral problems were assessed using the 25-item Strengths and Difficulties Questionnaire (SDQ). The SDQ is a behavioral screening measure that assesses psychological adjustment in 3-16 year-olds (R. Goodman, Meltzer, \& Bailey, 1998), and has also been described as measuring children's mental health or psychological well-being. The SDQ includes ten strengths, fourteen difficulties and one neutral item across five dimensions of emotional symptoms, conduct problems, hyperactivity, peer relationships, and prosocial behavior. Mothers reported their agreement with behavioral statements (not true, somewhat true, and certainly true) where higher scores indicate worse behavior. A total difficulties score is derived from the first four sub-scales. The prosocial dimension is not incorporated because prosocial behaviors are distinct from behavioral problems.

The SDQ has good psychometric properties: Exploratory factor analysis in 6-10 yearold British children identified internalizing and externalizing scales that accounted for 13.1 and $23.2 \%$ of common variance, with internal reliability of .69 and .91 . Confirmatory factor analysis indicated a good fit for these two factors $\left(\mathrm{x}^{2}(\mathrm{df})=218.83(64), \mathrm{RMSEA}\left(\mathrm{CI}_{95}\right)=.08\right.$ (0.078-0.083), CFI=.90, NFI=.91), with high internal consistency, as measured by Cronbach's alpha (r=.73 and .89) (Curvis, McNulty, \& Qualter, 2014). Sensitivity measured using the area under the curve is also high ( $\mathrm{r}=.87,95 \% \mathrm{CI}$ : .83-.91) (R. Goodman, 1997), and measurement invariance by age, sex, and ethnicity has been reported (Stone, Otten, Engels, Vermulst, \& Janssens, 2010). Screening tools like the SDQ are more inclusive than clinical diagnoses as many children fail to access or receive mental health care SDQ scores were log transformed to reduce skew.

Internalizing and externalizing behaviors are conceptually distinct, so were examined separately as they may have specific associations with income. Internalizing (inwardlydirected) behaviors were captured by combining emotional symptoms and peer relationships, 
and externalizing (outwardly-directed) behaviors were captured by combining conduct problems and hyperactivity. These two subscales have greater validity than the five individual subscales when examining specific behaviors (A. Goodman, Lamping, \& Ploubidis, 2010).

\section{Covariates.}

In all regressions we controlled for time-varying covariates relating to children (age and disability status), parents (mother's age and parents' highest education qualifications) and the household (housing tenure, family type and number of working parents). These covariates were each measured at every survey wave. We also controlled for the time-invariant covariate of children's sex.

\section{Data Analysis}

We used fixed-effects panel models to examine associations between absolute household income, distance from the mean income and income rank and children's behavioral problems. Fixed-effects panel models are a type of longitudinal model that capture how changes in a predictor variable over time are associated with changes in an outcome variable over time. The main challenge for statistical analyses is the potential influence of unobserved variance, where variables that are correlated with the predictor or outcome variables are not observed so cannot be controlled, potentially introducing bias. For example, higher-income parents may have other unmeasured influences on their children's behavior, such as high levels of motivation or good interpersonal skills. The fixed-effects assumption invoked here states that unobserved variance is associated with the predictor variables, in contrast to the random-effects assumption which states that unobserved variance is not associated with the predictor variables. While the random effects specification provides more efficient estimates, we used fixed-effects because unobserved variance may be associated 
with household incomes. Formal empirical comparison of the two specifications using the Hausman test also confirmed that random-effects models were unsuitable.

By exploiting the longitudinal structure of the Millennium Cohort Study, fixed-effects panel models use only within-child variation to estimate how changes in the predictor variable are associated with changes in the outcome variable. This serves to remove the influence of both observed and unobserved characteristics that remain stable over time, removing any possible bias introduced by these characteristics. It should be noted that fixedeffects models do not correct for observed and unobserved characteristics that do change over time. We therefore controlled for time-varying characteristics (age, disability status, housing tenure, family type, parents' education and working status) at each wave to account for changes in the characteristics of children, their parents and the household. Although this does not correct for unmeasured time-varying characteristics, this strategy provides the strongest possible test of the causal associations between income and children's behavioral problems.

We used linear models because unlike binary or count models, linear models utilize the full range of SDQ scores to provide the most detailed examination of children's behavioral problems (Mirowsky \& Ross, 2002). All results were replicated in sensitivity analyses using count models (see supplementary material).

The exclusion of multiple births removed family-level clustering; equally ward-level clustering accounted for just $4.21 \%$ of variance in SDQ scores so was ignored. Stratification characteristics were included in models to account for the sampling design. All analyses were undertaken using Stata 13 software.

\section{Modelling strategy.}

We first examined individual associations between each of the continuous household income variables and children's behavioral problems. We used fixed-effects panel models with log transformed SDQ scores as the continuous outcome measure. The predictor 
variables of (a) continuous absolute household income, (b) distance from the regional median and mean income, and (c) regional income rank were separately entered into individual fixedeffects panel models. Goodness-of-fit tests were used to compare the relative strength of associations between the income variables and children's behavioral problems. This captures the unique associations between each income variable and behavioral problems without any impact of shared variance between the income variables. This is important because the income variables have similar properties (see Table 2) and are correlated (Table 3).

\section{Comparing the fit of models that contain only one of the income variables therefore} provides a clear and direct way of identifying the income variable that is most closely associated with children's behavioral problems, with no possible influence of multicollinearity. Furthermore, a detailed examination of multicollinearity indicated that all models were robust to minor changes in model specification and were replicated in random subsets of the dataset, demonstrating that the possible influence of multicollinearity was trivial (available on request). Second, we entered (a) continuous distance from the regional median and mean and (b) continuous regional income rank into models after controlling for continuous absolute household income. This serves to control for shared variance between the income variables by capturing their unique associations with behavioral problems. This two-step strategy aimed to first identify the income variable that is most clearly associated with children's behavioral problems, and then confirm that this association does not reflect the influence of shared variance with absolute household income. Third, we examined interactions between continuous absolute household income and (a) distance from the regional median and mean tertile (high, middle, low), and (b) regional income rank tertile (high, middle, low) to test the possibility that absolute household income interacts with relative income measures to influence behavioral problems. We examined interactions between continuous absolute household income and tertiles of distance from the regional 
median and mean and regional income rank for ease of interpretation and graphical presentation. Fourth, we examined interactions between continuous absolute household income and (a) parents' work status, (b) parents' educational qualifications to explore the role of cumulative risk factors on children's behavioral problems. Finally, we included all interactions between continuous absolute household income and parents' work status, educational qualifications and (a) distance from the regional median and mean (high, middle, low), (b) regional income rank (high, middle, low) to test the robustness of the interaction terms. All analyses were repeated for internalizing and externalizing problems.

\section{Model fit.}

We used Akaike's Information Criterion (AIC) to compare non-nested models, which provide a measure of fit adjusted for model complexity. Differences of 1-2 identify comparable models while larger differences suggest worse fit (Spiegelhalter, Best, Carlin, \& van der Linde, 2002). Nested models were compared using likelihood ratio tests.

\section{Results}

\section{Absolute and Relative Income and Children's Behavioral Problems}

Table 4 shows the results of fixed-effects panel models examining associations between household income and children's behavioral problems, expressed as exponentiated coefficients. Exponentiated coefficients are interpreted as the increase in SDQ score for a one-unit increase in income, such that exponentiated values of less than one indicate lower SDQ scores among higher-income children. As the income variables have been normalized, a one-unit increase in income reflects an increase from the lowest- to the highest household income; dividing each exponentiated coefficient by 100 indicates the effect of a one percentage point increase in income on SDQ scores. Only the main effect of absolute household income was significantly associated with children's behavior: A 1\% increase in absolute household income (approximately $£ 11.48$ per week) was associated with $0.346 \%$ 
lower SDQ scores (Model 1), while increased distance from the mean (Model 2) and income rank (Model 3) were not associated with children's SDQ scores. After controlling for absolute household income, both distance from the mean (Model 4) and income rank (Model 5) became significant and AIC figures indicated large improvements to model fit, suggesting that children's behavioral problems are determined by a combination of income variables; both income in terms of material resources and income as a measure of status. Nonlinear main effects of income were examined but were no better fitting than models combining absolute household income with distance from the mean or income rank (Models 4 and 5).

\section{Multiple Socioeconomic Disadvantages and Children's Behavioral Problems}

Examination of interaction effects in Table 5 suggest that household income and other measures of socioeconomic disadvantage have a combined influence on children's SDQ scores. Significant interactions between continuous absolute household income and income rank tertile (Model 2) show that higher income rank was associated with additional improvements in children's behavioral problems at higher absolute household incomes, while interactions between continuous absolute household income and distance from the mean tertile (Model 1) demonstrate this to a very limited extent.

Further examination of interaction effects shows that the beneficial effects of increasing absolute household incomes on children's behavioral problems did not vary by parents' working status (Model 3), while increasing incomes were particularly beneficial to behavioral problems among children whose parents had school-level qualifications (Model 4). Model 2 displayed the best fit, suggesting that children's behavioral problems are best predicted by a combination of absolute household income and income rank.

The interactions between absolute household income and distance from the median and mean tertile remained unclear and non-significant when added to a final model that included interactions between absolute household income household and parents' working 
status and education (Model 5). In contrast, the interactions between continuous absolute household income and income rank tertile remained significant and of similar size when added to a final model including the interactions between absolute household income and parents' working status and education (Model 6), demonstrating that the positive impact of higher income rank was greater at higher absolute household incomes (Figure 1(a)).

The interaction between income and parents' working status become significant in Model 6, indicating that increasing incomes were more beneficial to children's behavioral problems in families where one or both parents worked than in workless families (Figure 1(b)). The previous interaction between income and school-level qualifications was no longer significant. The interaction between absolute household income and income rank was also robust after controlling for quadratic effects of absolute household income and income rank. Model 6 displayed improved fit $(p<.0001)$ over each of the previous models, indicating that behavioral problems in young children are most strongly influenced by a combination of the household's absolute material resources, their rank position within the regional income distribution (high, middle or low), and the number of working parents in the household.

The interactions between absolute household income and income rank displayed in Figure 1(a) are explored in further detail in Table 6. The vertical columns show the mean predicted SDQ scores at different levels of absolute household income for low-, middle- and high-ranking children. At the lowest absolute household incomes, SDQ scores did not vary according to income (mean predicted score of 19.57). Moving from the lowest to the highest absolute household income resulted in a larger reduction in SDQ scores for low (by $73.01 \%$ to 5.28 ) than high-ranking children (by $78.75 \%$ to 4.16 ). Equivalently, the horizontal rows show predicted SDQ scores for low-, middle- and high-ranking children at different levels of absolute household income. At the 40th percentile of absolute household income, predicted SDQ scores were $9.12 \%$ lower in high-ranking children (10.53) than low-ranking children 
(11.59). This difference was greater at the top of the income distribution, where predicted SDQ scores were $21.26 \%$ lower in high-ranking children (4.16) than low-ranking children (5.28). Both absolute household income and income rank therefore relate to children's behavioral problems, but the effects of absolute household income are larger.

The interactions between absolute household income and parents' working status displayed in Figure 1(b) are explored in Table 7. The vertical columns show the mean predicted SDQ scores at different levels of absolute household income by parents' working status. SDQ scores did not vary according to parents' working status at the lowest absolute household incomes (mean predicted score of 19.57). Moving from the lowest to the highest absolute household income resulted in a larger reduction in SDQ scores for children living in households where two parents worked (by $78.66 \%$ to 4.18 ) than one parent worked (by $75.39 \%$ to 4.82 ) or no parent worked (by $68.53 \%$ to 6.16 ). Equivalently, the horizontal rows show predicted SDQ scores by parents' working status at different levels of absolute household incomes. At the 40th percentile, predicted SDQ scores were $14.39 \%$ lower among children living in households where two (10.55) than no parent worked (12.32). This difference was greater at larger incomes: At the top of the income distribution, predicted SDQ scores were $32.18 \%$ lower among children living in households where two parents (4.18) than no parent worked (6.16).

\section{Absolute and Relative Income and Internalizing and Externalizing}

The final models (containing all interaction terms for distance from the median and mean tertile and income rank tertile) were examined separately for internalizing and externalizing problems. Consistent with the results for children's overall behavioral problems, children's internalizing and externalizing problems were not clearly associated with distance from the median and mean tertile (Table 4). Instead, children's internalizing and externalizing problems were associated with a combination of the household's absolute 
material resources, their rank position within the regional income distribution, and the number of working parents in the household. The coefficients for these variables were extremely consistent for internalizing and externalizing problems, indicating that absolute and relative incomes are equally important to children's inwardly and outwardly directed behaviors. This result provides a further robustness check by demonstrating that the importance of income to children's overall behavioral problems reflected equally strong associations with internalizing and externalizing problems. Separate examinations of boys and girls revealed no sex differences in these associations for total SDQ scores, internalizing or externalizing problems (see supplementary material).

\section{Discussion}

In this study we examined the comparative relevance of absolute and relative household incomes to behavioral problems in 3-12 year-old children in the UK. In longitudinal analyses, children's behavioral problems were predicted by an interaction between absolute household income and regional income rank in which higher absolute household incomes were associated with lower behavioral problems across the income distribution, while higher regional income rank was associated with lower behavioral problems only among children living in higher-income households. The role of reference incomes (distance from the regional median and mean income and Yitzhaki income) on children's behavioral problems was unclear. Increasing absolute household incomes also conferred greater improvements to behavioral problems among children living in working families. All our results were replicated for both internalizing and externalizing problems, and in boys and girls. Our results provide the first evidence for the role of individual-level relative income on children's behavioral problems, suggesting that even young children might be influenced by their household's income rank, where the negative impact of incomebased status comparisons appear to be confined to economically advantaged children. 


\section{Comparisons with Previous Research}

The relevance of income rank to children's behavioral problems is broadly consistent with past research reporting associations between relative income and infants' physical health (Lhila \& Simon, 2010; Reagan et al., 2007), affluence rank and adolescents' psychosomatic symptoms (Elgar, Baranek, Saul, \& Napoletano, 2013; Elgar, De Clercq, et al., 2013), and income rank and adults' mental health (Hounkpatin et al., 2015; Wetherall et al., 2015; Wood, Boyce, et al., 2012). It also replicates evidence for rank-based cognitive judgments in both laboratory studies (eg: Brown et al., 2008) and survey research (eg: C. J. Boyce et al., 2010). Taken together, our results strengthen the evidence base for rank theory and indicate that the role of relative position to children's behavioral problems reflect rank, not median- or mean-based judgments.

Evidence for mean-based income comparisons (distance from the regional median and mean income and Yitzhaki income) on children's behavioral problems was conversely far weaker. This novel result is important because past research has not reached a consensus over why income-based status comparisons are so detrimental to mental health. Our results demonstrate that at the top of the income distribution - where incomes are well dispersed measures of relative income based on regional income rank are more relevant to children's behavioral problems than those measuring distance from the regional median and mean. By demonstrating that children are more sensitive to income rank than two different specifications of average-based incomes, our results support rank theory and suggest an evolutionary-based cognitive explanation for the negative association between income and children's behavioral problems.

Contrary to our hypothesis, income rank was more relevant to children's behavioral problems at high levels of absolute household income. This observation also challenges cross-sectional research reporting that affluence rank was more closely associated with 
adolescents' psychosomatic symptoms at low levels of absolute affluence (Elgar, De Clercq, et al., 2013). Income or affluence rank may genuinely have different associations with behavioral problems in children and adolescents, which might reflect the increasing importance of social evaluation with age (van den Bos, de Rooij, Miers, Bokhorst, \& Westenberg, 2014). These discrepancies could alternatively reflect methodological differences as Elgar, De Clercq, et al. (2013) used a less detailed measure of family affluence and were restricted to cross-sectional analyses, introducing the possibility of reverse causality. In contrast, the fixed-effects panel models and continuous income data used in the current study provided a stronger assessment of the effects of absolute and relative incomes on children's behavioral problems.

When considering the effects of cumulative socioeconomic disadvantage, higher absolute household income was associated with greater improvements to behavioral problems among children living in working families relative to those in workless families, replicating prior evidence that behavioral problems are lowest in children living in dual earner households, independent of income (McMunn, Kelly, Cable, \& Bartley, 2012). This confirmed our hypothesis and is consistent with the cumulative risk model by indicating the role of reinforcing advantages, where household income from earnings is more beneficial to children's behavioral problems than income from other sources. In contrast, interactions between income and parents' education were not significant when all interaction terms were included. These differences suggest that parents' working status and educational qualifications have distinct associations with children's behavioral problems. While parents' working status relates to households' current circumstances, educational qualifications capture parents' earlier life experiences. Our results suggest that the combined roles of income and current than past measures of families' socioeconomic circumstances are more relevant to children's behavioral problems. 
Our results were replicated for internalizing and externalizing behaviors and the comparability of these results suggests that the consequences of low incomes are manifested equally in inwardly- and outwardly- directed behaviors. This observation contrasts with past research reporting that socioeconomic status is more closely associated with children's externalizing than internalizing problems (Amone-P'Olak et al., 2009; Bøe et al., 2012). This discrepancy may reflect developmental differences in how children perceive or respond to low incomes or feelings of defeat and should be explored further. The absence of sex differences in the associations between incomes and internalizing and externalizing problems demonstrates that absolute household income, income rank and parents' working status are equally relevant to inwardly- and outwardly- directed behavioral problems in boys and girls.

\section{Policy Implications}

Our results point to two key policy implications. First, the relevance of absolute household incomes to behavioral problems across the income distribution makes it important to increase household incomes. This is important because childhood behavioral problems have negative consequences both for children's quality of life (Bastiaansen et al., 2004) and adult experiences (Delaney \& Smith, 2015; Egan et al., 2015; Kim-Cohen et al., 2003). Addressing the negative consequences of low incomes on children's behavioral problems could therefore improve both children's current and their future adult outcomes.

Second, therapeutic strategies aimed at reducing the frequency and salience of social comparisons (Johnson \& Swendsen, 2014) could also be beneficial. Relatedly, health professionals working with children from higher-income households should be made aware of the potential effects of relative income or status comparisons to avoid behavioral problems in this group from being erroneously underestimated or overlooked (Luthar \& Latendresse, 2005). 


\section{Strengths and Limitations}

The study's main strength is its longitudinal design and panel analysis, which removes the confounding effects of stable unobserved individual characteristics. This is important when examining behavioral problems as some effects cannot be reliably measured (e.g.: genetic influences), while others (e.g.: home environment) are more difficult to capture. Directly comparing the predictive strength of absolute household income, distance from the regional median and mean and regional income rank provides the strongest indication possible with survey data that a combination of absolute household income and income rank might exert a causal influence on children's behavior. Additionally, all results were replicated in sensitivity analyses using count models, demonstrating that our results were not limited to estimates from linear fixed-effects panel models (see supplementary material).

A second key strength is the use of continuous income data. Research on children commonly employs proxy measures of affluence based on the ownership of certain material goods to maximize accuracy and minimize item nonresponse. Using continuous household income provides a more discriminating means of exploring the associations between income and behavioral problems.

The study's main limitation is the reliance on parent-rated child behavioral problems over diagnostic measures, as bias and negative affectivity might affect the accuracy of parental reports. However, SDQ scores are consistent with clinical outcomes (R. Goodman, Ford, Simmons, Gatward, \& Meltzer, 2000), and previous research suggests that mothers are reliable informants about their children's behavioral problems (Richters, 1992). Furthermore, each of our results were replicated in sensitivity analysis controlling for maternal distress, demonstrating that our results were not due to measurement bias from distressed mothers (available on request). 
We defined income rank and distance from the mean using regional comparison groups. Our aims were not to explore different comparison groups so cannot show that regional comparisons are more relevant to children's behavioral problems than those based on other characteristics. Whom household incomes are compared against is a recognized limitation of relative income accounts and further research is needed. Nonetheless, income inequality is more strongly associated with adults' mental health when defined at a larger geographic scale (Wilkinson \& Pickett, 2006), and regional comparisons are relevant to mental health in adults (Wetherall et al., 2015; Wood, Boyce, et al., 2012) and adolescents (Elgar, De Clercq, et al., 2013). Moreover, a comparison of reference groups reported that relative income was more closely associated with adults' self-rated health and allostatic load when calculated within regions than other potential comparison groups (Hounkpatin et al., 2016), reinforcing the suitability of regional reference groups. It was not possible to explore school-based comparison groups as others (eg: Elgar, Baranek, et al., 2013; Elgar, De Clercq, et al., 2013) have because school data is not consistently available throughout the survey.

Additionally, in attempting to identify the roles of absolute and relative income on children's behavioral problems, we did not specifically examine parenting behaviors, despite their relevance to children's behavioral problems (Mistry, Vandewater, Huston, \& McLoyd, 2002). Future work should address this omission.

\section{Future Directions}

Our results are partially consistent with previous evidence from adolescents and adults. In future it will be possible to extend the analyses over a longer time period to determine the relevance of absolute and relative household incomes to children's behavioral problems as the MCS cohort becomes older. Exploring these associations as the cohort members reach adolescence may help explain the different results from children and adolescents. 
We used objectively defined measures of relative income based on absolute household income, which have the advantage of avoiding the possibly biasing effects of shared method variance that can arise when examining associations between two self-report measures. Objectively defined rank is also consistent with the evolutionary component of rank theory. Others have reported that mental health is associated with subjective assessments of perceived social position (Demakakos, Nazroo, Breeze, \& Marmot, 2008), but whether objective measures of relative income translate into subjective perceptions of relative income has, however, not yet been established. Moreover, evidence that young children are sensitive to social stratification (Malloy et al., 2007; Tudor, 1971) and that subjective status is associated with children's behavioral problems (W. T. Boyce et al., 2012) collectively suggest that subjective perceptions of relative income might be relevant to children's behavioral problems. Future research exploring children's perceptions of relative income and their associations with behavioral problems would therefore extend the results of the current study.

\section{Conclusions}

We have undertaken the first examination of absolute and relative household income in relation to children's behavioral problems. Using longitudinal analysis, higher absolute household incomes were associated with lower behavioral problems across the income distribution, while regional income rank was associated with lower behavioral problems only at the highest incomes. Relative income is therefore more relevant to behavioral problems in economically advantaged children. Higher absolute household incomes were also associated with lower behavioral problems among children in working households, indicating compounding effects of income and socioeconomic advantages.

Income rank displayed clearer associations with children's psychological distress than median-and mean-based income comparisons (both distance from the regional median and 
mean income and Yitzhaki income), providing initial evidence supporting an evolutionary explanation for the negative association between household income and children's behavioral problems. This novel result is important because past research on adults has not reached a consensus over why income-based status comparisons are so detrimental to mental health. Both absolute and relative incomes are therefore relevant to policy interventions aimed at reducing the negative association between household income and children's behavioral problems. The observation that even young children's behavioral problems were influenced by their household's relative income also has implications for understanding children's broader development. 


\section{References}

Aldrovandi, S., Brown, G. D. A., \& Wood, A. M. (2015). Social norms and rank-based nudging: Changing willingness to pay for health food. Journal of Experimental Psychology: Applied, 21, 242-254. http://doi.org/10.1037/xap0000048

Amone-P’Olak, K., Burger, H., Ormel, J., Huisman, M., Verhulst, F. C., \& Oldehinkel, A. J. (2009). Socioeconomic position and mental health problems in pre- and earlyadolescents: The TRAILS study. Social Psychiatry and Psychiatric Epidemiology, 44, 231-238. http://doi.org/10.1007/s00127-008-0424-z

Attar, B. K., Guerra, N. G., \& Tolan, P. H. (1994). Neighborhood disadvantage, stressful life events, and adjustment in urban elementary-school children. Journal of Clinical Child Psychology, 23, 391-400. http://doi.org/10.1207/s15374424jccp2304_5

Bastiaansen, D., Koot, H. M., Ferdinand, R. F., \& Verhulst, F. C. (2004). Quality of life in children with psychiatric disorders: Self-, parent, and clinician report. Journal of the American Academy of Child and Adolescent Psychiatry, 43, 221-230. http://doi.org/10.1097/00004583-200402000-00019

Belsky, J., Domitrovich, C. E., \& Crnic, K. (1997). Temperament and parenting antecedents of individual differences in three-year-old boys' pride and shame reactions. Child Development, 68, 456-466. http://doi.org/10.1111/j.1467-8624.1997.tb01951.x

Bøe, T., Øverland, S., Lundervold, A. J., \& Hysing, M. (2012). Socioeconomic status and children's mental health: Results rom the Bergen Child Study. Social Psychiatry and Psychiatric Epidemiology, 47, 1557-1566. http://doi.org/10.1007/s00127-011-0462-9

Boyce, C. J., Brown, G. D. A., \& Moore, S. C. (2010). Money and happiness: Rank of income, not income, affects life satisfaction. Psychological Science, 21, 471-475. http://doi.org/10.1177/0956797610362671

Boyce, W. T., Obradovic, J., Bush, N. R., Stamperdahl, J., Kim, Y. S., \& Adler, N. (2012). 
Social stratification, classroom climate, and the behavioral adaptation of kindergarten children. Proceedings of the National Academy of Sciences, 109, 17168-17173. http://doi.org/10.1073/pnas.1201730109

Brown, G. D. A., Gardner, J., Oswald, A., \& Qian, J. (2008). Does wage rank affect employees' well-being? Industrial Relations, 47, 355-389.

http://doi.org/10.1111/j.1468-232X.2008.00525.x

Clark, A., Masclet, D., \& Villeval, M.-C. (2008). Effort and comparison income: Experimental and survey evidence. Centre for Economic Performance Discussion Paper No 886. Bonn: Institute for the Study of Labor.

Curvis, W., McNulty, S., \& Qualter, P. (2014). The validation of the self-report Strengths and Difficulties Questionnaire for use by 6- to 10-year-old children in the UK. British Journal of Clinical Psychology, 53, 131-137. http://doi.org/10.1111/bjc.12025

Daly, M., Boyce, C., \& Wood, A. M. (2015). A social rank explanation of how money influences health. Health Psychology, 34, 222-230. http://doi.org/10.1037/hea0000098

Delaney, L., \& Smith, J. P. (2015). Childhood health: Trends and consequences over the life course. The Future of Children, 22, 43-63. http://doi.org/10.1353/foc.2012.0003

Demakakos, P., Nazroo, J., Breeze, E., \& Marmot, M. (2008). Socioeconomic status and health: The role of subjective social status. Social Science \& Medicine, 67, 330-340. http://doi.org/10.1016/j.socscimed.2008.03.038

Dickerson, S. S., \& Kemeny, M. E. (2004). Acute stressors and cortisol responses: A theoretical investigation and synthesis of laboratory research. Psychological Bulletin, 130, 355-391. http://doi.org/10.1037/0033-2909.130.3.355

Egan, M., Daly, M., \& Delaney, L. (2015). Childhood psychological distress and youth unemployment: Evidence from two British cohort studies. Social Science \& Medicine, 124, 11-17. http://doi.org/10.1016/j.socscimed.2014.11.023 
Elgar, F. J., Baranek, H., Saul, G., \& Napoletano, A. (2013). Relative deprivation and mental health in Canadian adolescents. International Journal of Clinical Psychiatry and Mental Health, 1, 33-40. http://doi.org/10.12970/2310-8231.2013.01.01.4

Elgar, F. J., De Clercq, B., Schnohr, C. W., Bird, P., Pickett, K. E., Torsheim, T., ... Currie, C. (2013). Absolute and relative family affluence and psychosomatic symptoms in adolescents. Social Science \& Medicine, 91, 25-31. http://doi.org/10.1016/j.socscimed.2013.04.030

Geraci, A., \& Surian, L. (2011). The developmental roots of fairness: infants' reactions to equal and unequal distributions of resources. Developmental Science, 14, 1012-1020. http://doi.org/10.1111/j.1467-7687.2011.01048.x

Goodman, A., Lamping, D. L., \& Ploubidis, G. B. (2010). When to use broader internalising and externalising subscales instead of the hypothesised five subscales on the Strengths and Difficulties Questionnaire (SDQ): Data from British parents, teachers and children. Journal of Abnormal Child Psychology, 38, 1179-1191. http://doi.org/10.1007/s10802010-9434-X

Goodman, R. (1997). The Strengths and Difficulties Questionnaire: A research note. Journal of Child Psychology and Psychiatry, 38, 581-586. http://doi.org/10.1111/j.14697610.1997.tb01545.x

Goodman, R., Ford, T., Simmons, H., Gatward, R., \& Meltzer, H. (2000). Using the Strengths and Difficulties Questionnaire (SDQ) to screen for child psychiatric disorders in a community sample. British Journal of Psychiatry, 177, 534-539. http://doi.org/10.1192/bjp.177.6.534

Goodman, R., Meltzer, H., \& Bailey, V. (1998). The Strengths and Difficulties Questionnaire: A pilot study on the validity of the self-report version. European Child and Adolescent Psychiatry, 7, 125-130. http://doi.org/10.1007/s007870050057 
Green, H., McGinnity, A., Meltzer, H., Ford, T., \& Goodman, R. (2005). Mental health of children and young people in Great Britain, 2004. Hampshire: Palgrave Macmillan.

Griffiths, A. W., Wood, A. M., Maltby, J., Taylor, P. J., \& Tai, S. (2014). The prospective role of defeat and entrapment in depression and anxiety: A 12-month longitudinal study. Psychiatry Research, 216, 52-59. http://doi.org/10.1016/j.psychres.2014.01.037

Hounkpatin, H. O., Wood, A. M., Brown, G. D. A., \& Dunn, G. (2015). Why does income relate to depressive symptoms? Testing the income rank hypothesis longitudinally. Social Indicators Research, 124, 637-655. http://doi.org/10.1007/s11205-014-0795-3

Hounkpatin, H. O., Wood, A. M., \& Dunn, G. (2016). Does income relate to health due to psychosocial or material factors? Consistent support for the psychosocial hypothesis requires operationalization with income rank not the Yitzhaki Index. Social Science \& Medicine, 150, 76-84. http://doi.org/doi:10.1016/j.socscimed.2015.12.008

Johnson, E. I., \& Swendsen, J. D. (2014). Perceived social status and early adolescents' responses to negative daily events. Journal of Child and Family Studies, 24, 1593-1604. http://doi.org/10.1007/s10826-014-9963-y

Keltner, D., Young, R., \& Buswell, B. N. (1997). Appeasement in human emotion, personality, and social practice. Aggressive Behavior, 23, 359-374. http://doi.org/10.1002/(SICI)1098-2337(1997)23:5<359::AID-AB5>3.0.CO;2-D

Kim-Cohen, J., Caspi, A., Moffitt, T. E., Harrington, H., Milne, B. J., \& Poulton, R. (2003). Prior juvenile diagnoses in adults with mental disorder: Developmental follow-back of a prospective-longitudinal cohort. Archives of General Psychiatry, 60, 709-717. http://doi.org/10.1001/archpsyc.60.7.709

Kryski, K. R., Smith, H. J., Sheikh, H. I., Singh, S. M., \& Hayden, E. P. (2013). HPA axis reactivity in early childhood: Associations with symptoms and moderation by sex. Psychoneuroendocrinology, 38, 2327-2336. 
http://doi.org/10.1016/j.psyneuen.2013.05.002

Kuo, C. T., \& Chiang, T. L. (2013). The association between relative deprivation and selfrated health, depressive symptoms, and smoking behavior in Taiwan. Social Science and Medicine, 89, 39-44. http://doi.org/10.1016/j.socscimed.2013.04.015

Lewis, M., \& Ramsay, D. (2002). Cortisol response to embarrassment and shame. Child Development, 73, 1034-1045. http://doi.org/10.1111/1467-8624.00455

Lhila, A., \& Simon, K. I. (2010). Relative deprivation and child health in the USA. Social Science \& Medicine, 71, 777-785. http://doi.org/10.1016/j.socscimed.2010.03.058

Lorant, V., Deliège, D., Eaton, W., Robert, A., Philippot, P., \& Ansseau, M. (2003). Socioeconomic inequalities in depression. A meta-analysis. American Journal of Epidemiology, 157, 98-112. http://doi.org/10.1093/aje/kwf182

Luthar, S. S., \& Latendresse, S. J. (2005). Children of the affluent: Challenges to well-being. Current Directions in Psychological Science, 14, 49-53. http://doi.org/10.1111/j.09637214.2005.00333.x

Malloy, T. E., Albright, L., \& Scarpati, S. (2007). Awareness of peers' judgments of oneself: Accuracy and process of metaperception. International Journal of Behavioral Development, 31, 603-610. http://doi.org/10.1177/0165025407080590

McLaughlin, K. A., Costello, E. J., Leblanc, W., Sampson, N. a., \& Kessler, R. C. (2012). Socioeconomic status and adolescent mental disorders. American Journal of Public Health, 102, 1742-1750. http://doi.org/10.2105/AJPH.2011.300477

McMunn, A., Kelly, Y., Cable, N., \& Bartley, M. (2012). Maternal employment and child socio-emotional behaviour in the UK: Longitudinal evidence from the UK Millennium Cohort Study. Journal of Epidemiology and Community Health, 66, 950-957. http://doi.org/10.1136/jech.2010.109553

Melrose, K., Brown, G. D. A., \& Wood, A. M. (2013). Am I abnormal? Relative rank and 
social norm effects in judgments of anxiety and depression symptom severity. Journal of Behavioral Decision Making, 26, 174-184. http://doi.org/10.1002/bdm.1754

Mirowsky, J., \& Ross, C. E. (2002). Measurement for a human science. Journal of Health and Social Behavior, 43, 152-170. http://doi.org/10.2307/3090194

Mistry, R. S., Vandewater, E. A., Huston, A. C., \& McLoyd, V. C. (2002). Economic wellbeing and children's social adjustment: The role of family process in an ethnically diverse low-income sample. Child Development, 73, 935-951. http://doi.org/10.1111/1467-8624.00448

Mullett, T. L., \& Tunney, R. J. (2013). Value representations by rank order in a distributed network of varying context dependency. Brain and Cognition, 82, 76-83. http://doi.org/10.1016/j.bandc.2013.02.010

Pickett, K. E., James, O. J., \& Wilkinson, R. G. (2006). Income inequality and the prevalence of mental illness: A preliminary international analysis. Journal of Epidemiology and Community Health, 60, 646-647. http://doi.org/10.1136/jech.2006.046631

Pickett, K. E., \& Wilkinson, R. G. (2007). Child wellbeing and income inequality in rich societies: Ecological cross sectional study. BMJ, 335, 1080-1085. http://doi.org/10.1136/bmj.39377.580162.55

Pickett, K. E., \& Wilkinson, R. G. (2015). The ethical and policy implications of research on income inequality and child well-being. Pediatrics, 135, S39-S47. http://doi.org/10.1542/peds.2014-3549E

Plewis, I. (2007). Non-response in a birth cohort study: The case of the Millennium Cohort Study. International Journal of Social Research Methodology, 10, 325-334. http://doi.org/10.1080/13645570701676955

Reagan, P. B., Salsberry, P. J., \& Olsen, R. J. (2007). Does the measure of economic disadvantage matter? Exploring the effect of individual and relative deprivation on 
intrauterine growth restriction. Social Science \& Medicine, 64, 2016-2029. http://doi.org/10.1016/j.socscimed.2007.02.022

Richters, J. E. (1992). Depressed mothers as informants about their children - A criticalreview of the evidence for distortion. Psychological Bulletin, 112, 485-499. http://doi.org/10.1037/0033-2909.112.3.485

Shively, C. A., Laber-Laird, K., \& Anton, R. F. (2000). Behaviour and physiology of social stress and depression in female cynomolgus monkeys. In I. Kawachi, B. P. Kennedy, \& R. G. Wilkinson (Eds.), The society and population health reader. Volume 1: Income inequality and health (Vol. 1, pp. 405-420). New York: The New Press.

Siddaway, A. P., Taylor, P. J., Wood, A. M., \& Schulz, J. (2015). A meta-analysis of perceptions of defeat and entrapment in depression, anxiety problems, posttraumatic stress disorder, and suicidality. Journal of Affective Disorders, 184, 149-159. http://doi.org/10.1016/j.jad.2015.05.046

Spiegelhalter, D. J., Best, N. G., Carlin, B. P., \& van der Linde, A. (2002). Bayesian measures of model complexity and fit. Journal of the Royal Statistical Society B, 64, 583-639. http://doi.org/10.1111/1467-9868.00353

Stone, L. L., Otten, R., Engels, R. C. M. E., Vermulst, A. A., \& Janssens, J. M. A. M. (2010). Psychometric properties of the parent and teacher versions of the Strengths and Difficulties Questionnaire for 4- to 12-year-olds: A review. Clinical Child and Family Psychology Review, 13, 254-274. http://doi.org/10.1007/s10567-010-0071-2

Taylor, P. J., Gooding, P., Wood, A. M., \& Tarrier, N. (2011). The role of defeat and entrapment in depression, anxiety, and suicide. Psychological Bulletin, 137, 391-420. http://doi.org/10.1037/a0022935

Tudor, J. F. (1971). The development of class awareness in children. Social Forces, 49, 470476. http://doi.org/10.2307/3005738 
van den Bos, E., de Rooij, M., Miers, A. C., Bokhorst, C. L., \& Westenberg, P. M. (2014). Adolescents' increasing stress response to social evaluation: Pubertal effects on cortisol and alpha-amylase during public speaking. Child Development, 85, 220-236. http://doi.org/10.1111/cdev.12118

Wetherall, K., Daly, M., Robb, K. A., Wood, A. M., \& O’Connor, R. C. (2015). Explaining the income and suicidality relationship: Income rank is more strongly associated with suicidal thoughts and attempts than income. Social Psychiatry and Psychiatric Epidemiology, 50, 929-937. http://doi.org/10.1007/s00127-015-1050-1

Wethingon, E. (2000). Contagion of stress. In Advances in Group Processes (pp. 229-253). Emerald Group Publishing Limited.

Wilkinson, R. G., \& Pickett, K. E. (2006). Income inequality and population health: A review and explanation of the evidence. Social Science \& Medicine, 62, 1768-1784. http://doi.org/10.1016/j.socscimed.2005.08.036

Wood, A. M., Boyce, C. J., Moore, S. C., \& Brown, G. D. A. (2012). An evolutionary based social rank explanation of why low income predicts mental distress: A 17 year cohort study of 30,000 people. Journal of Affective Disorders, 136, 882-888. http://doi.org/10.1016/j.jad.2011.09.014

Wood, A. M., Brown, G. D. A., \& Maltby, J. (2011). Thanks, but I'm used to better: A relative rank model of gratitude. Emotion, 11, 175-180. http://doi.org/10.1037/a0021553

Wood, A. M., Brown, G. D. A., Maltby, J., \& Watkinson, P. (2012). How are personality judgments made? A cognitive model of reference group effects, personality scale responses, and behavioral reactions. Journal of Personality, 80, 1275-1311. http://doi.org/10.1111/j.1467-6494.2012.00763.x.

Yitzhaki, S. (1979). Relative deprivation and the Gini Coefficient. Quarterly Journal of Economics, 93, 321-324. http://doi.org/10.2307/1883197 


\section{Tables and Figures}

Table 1

Descriptive statistics of children's characteristics at waves 2-5 of the MCS

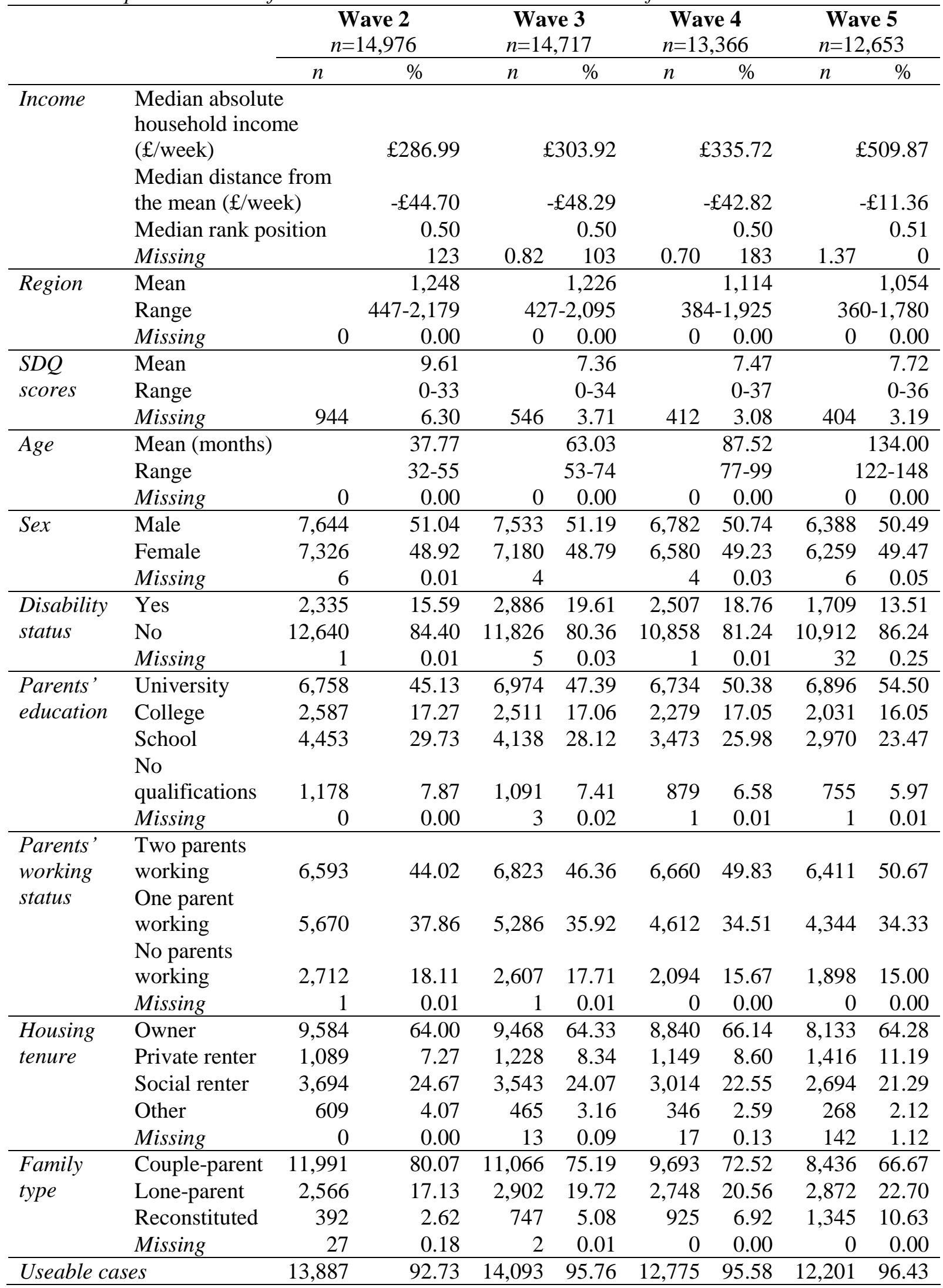


Table 2

Descriptive statistics of the income variables at waves 2-5 of the MCS

\begin{tabular}{llrrrr}
\hline \multicolumn{1}{c}{} & Wave 2 & Wave 3 & Wave 4 & Wave 5 \\
\hline Absolute & Mean & 330.99 & 347.78 & 384.67 & 525.99 \\
$\begin{array}{l}\text { household } \\
\text { income }\end{array}$ & Median & 286.99 & 303.92 & 335.72 & 509.87 \\
& Range & $11.75-$ & $11.67-$ & $11.67-$ & $90.88-$ \\
& & $1,362.18$ & $1,282.94$ & $1,282.54$ & $1,516.77$ \\
& Standard & & & & \\
& deviation & 219.09 & 217.54 & 227.86 & 218.67 \\
\hline Distance & Mean & -1.32 & -1.49 & -0.21 & 3.76 \\
from the & Median & -44.70 & -48.29 & -42.82 & -11.36 \\
mean & Range & $-371.33-$ & $-398.27-$ & $-441.29-$ & $-491.30-$ \\
& & 987.25 & 950.43 & 910.51 & 977.87 \\
& Standard & & & & \\
& deviation & 215.73 & 214.33 & 224.23 & 209.96 \\
\hline $\begin{array}{l}\text { Income } \\
\text { rank }\end{array}$ & Mean & $1,433.92$ & $1,412.23$ & $1,284.79$ & $1,252.48$ \\
& Median & $1,296.50$ & $1,285.50$ & $1,174.50$ & $1,166.50$ \\
& Range & $1.00-$ & $1.00-$ & $1.00-$ & $1.00-$ \\
& & $4,425.50$ & $4,269.50$ & $3,916.50$ & $3,705.50$ \\
& Standard & & & & \\
& deviation & 985.99 & 964.91 & 869.28 & 824.40 \\
\hline
\end{tabular}

Table 3

Intercorrelations between the income variables at waves 2-5 of the MCS

\begin{tabular}{llccc}
\hline & Wave 2 & Wave 3 & Wave 4 & Wave 5 \\
\hline $\begin{array}{l}\text { Absolute household income and } \\
\text { distance from the mean }\end{array}$ & 0.9045 & 0.9197 & 0.9223 & 0.9545 \\
\hline $\begin{array}{l}\text { Absolute household income and } \\
\text { income rank }\end{array}$ & 0.9467 & 0.9580 & 0.9505 & 0.9439 \\
\hline $\begin{array}{l}\text { Distance from the mean and income } \\
\text { rank }\end{array}$ & 0.9203 & 0.9183 & 0.9242 & 0.9639 \\
\hline
\end{tabular}

Table 4:

Panel regression analyses of children's $S D Q$ scores predicted by exponentiated coefficients of absolute household income, distance from mean income and income rank and interactions between income variables, adjusted for covariates $(n=52,956)$

\begin{tabular}{|c|c|c|c|c|c|}
\hline & Model 1 & Model 2 & Model 3 & Model 4 & Model 5 \\
\hline \multicolumn{6}{|c|}{ Fixed effects (exponentiated coefficients, se) } \\
\hline Absolute income & $\begin{array}{r}0.654 * * * \\
(0.017)\end{array}$ & & & $\begin{array}{r}0.414 * * * \\
(0.016)\end{array}$ & $\begin{array}{r}0.301 * * * \\
(0.013)\end{array}$ \\
\hline $\begin{array}{l}\text { Distance from the } \\
\text { mean }\end{array}$ & & $\begin{array}{r}0.996 \\
(0.023)\end{array}$ & & $\begin{array}{r}1.748 * * * \\
(0.058)\end{array}$ & \\
\hline $\begin{array}{l}\text { Income } \\
\text { rank }\end{array}$ & & & $\begin{array}{r}0.998 \\
(0.016) \\
\end{array}$ & & $\begin{array}{r}1.797 * * * \\
(0.048) \\
\end{array}$ \\
\hline \multicolumn{6}{|l|}{ Goodness-of-fit } \\
\hline Log likelihood & $-22,949$ & $-23,140$ & $-23,140$ & $-22,746$ & $-22,600$ \\
\hline AIC & 45,928 & 46,309 & 46,309 & 45,523 & 45,232 \\
\hline
\end{tabular}


Table 5

Panel regression analyses of children's $S D Q$ scores predicted by exponentiated coefficients of interactions between absolute household income and measures of socioeconomic disadvantage $(n=52,956)$

\begin{tabular}{|c|c|c|c|c|c|c|}
\hline & Model 1 & Model 2 & Model 3 & Model 4 & Model 5 & Model 6 \\
\hline \multicolumn{7}{|c|}{ Fixed effects (exponentiated coefficients, se) } \\
\hline Absolute income & $\begin{array}{r}0.389 * * * \\
(0.016)\end{array}$ & $\begin{array}{r}0.292 * * * \\
(0.013)\end{array}$ & $\begin{array}{r}0.682 * * * \\
(0.038)\end{array}$ & $\begin{array}{r}0.685 * * * \\
(0.026)\end{array}$ & $\begin{array}{r}0.456 * * * \\
(0.034)\end{array}$ & $\begin{array}{r}0.362 * * * \\
(0.027)\end{array}$ \\
\hline $\begin{array}{l}\text { Distance from the } \\
\text { mean }\end{array}$ & $\begin{array}{r}1.798 * * * \\
(0.070)\end{array}$ & & & & $\begin{array}{r}1.861 * * * \\
(0.074)\end{array}$ & \\
\hline Income rank & & $\begin{array}{r}2.442 * * * \\
(0.095)\end{array}$ & & & & $\begin{array}{r}2.468 * * * \\
(0.096)\end{array}$ \\
\hline No parents working & & & $\begin{array}{r}1.000 \\
(0)\end{array}$ & & $\begin{array}{r}1.000 \\
(0)\end{array}$ & $\begin{array}{r}1.000 \\
(0)\end{array}$ \\
\hline One parent working & & & $\begin{array}{r}1.012 \\
(0.036)\end{array}$ & & $\begin{array}{r}1.134 * * * \\
(0.042)\end{array}$ & $\begin{array}{r}1.116^{* *} \\
(0.041)\end{array}$ \\
\hline Two parents working & & & $\begin{array}{r}1.065 \\
(0.042)\end{array}$ & & $\begin{array}{r}1.257 * * * \\
(0.054)\end{array}$ & $\begin{array}{r}1.196 * * * \\
(0.051)\end{array}$ \\
\hline University & & & & $\begin{array}{r}1.000 \\
(0)\end{array}$ & $\begin{array}{r}1.000 \\
(0)\end{array}$ & $\begin{array}{r}1.000 \\
(0)\end{array}$ \\
\hline College & & & & $\begin{array}{r}1.080 \\
(0.050)\end{array}$ & $\begin{array}{r}1.006 \\
(0.047)\end{array}$ & $\begin{array}{r}1.066 \\
(0.049)\end{array}$ \\
\hline School & & & & $\begin{array}{l}1.081^{*} \\
(0.043)\end{array}$ & $\begin{array}{r}1.004 \\
(0.041)\end{array}$ & $\begin{array}{r}1.065 \\
(0.043)\end{array}$ \\
\hline $\begin{array}{l}\text { No educational } \\
\text { qualifications }\end{array}$ & & & & $\begin{array}{r}1.095 \\
(0.075) \\
\end{array}$ & $\begin{array}{r}1.012 \\
(0.072) \\
\end{array}$ & $\begin{array}{r}1.067 \\
(0.075) \\
\end{array}$ \\
\hline \multicolumn{7}{|l|}{ Interaction effects } \\
\hline Absolute income $\mathrm{X}$ & $1.059 * * *$ & & & & $1.075^{* * *}$ & \\
\hline Middle DFM & $(0.016)$ & & & & $(0.017)$ & \\
\hline Absolute income $\mathrm{X}$ & 1.022 & & & & $1.057 * *$ & \\
\hline High DFM & $(0.021)$ & & & & $(0.022)$ & \\
\hline Absolute income $\mathrm{X}$ & & $0.873 * * *$ & & & & $0.887 * * *$ \\
\hline Middle rank & & $(0.016)$ & & & & $(0.016)$ \\
\hline Absolute income $\mathrm{X}$ & & $0.764 * * *$ & & & & $0.787 * * *$ \\
\hline High rank & & $(0.020)$ & & & & $(0.021)$ \\
\hline Absolute income $\mathrm{X}$ & & & 0.997 & & $0.793 * * *$ & $0.782 * * *$ \\
\hline One parent working & & & $(0.065)$ & & $(0.055)$ & $(0.054)$ \\
\hline Absolute income $\mathrm{X}$ & & & 0.902 & & $0.659 * * *$ & $0.678 * * *$ \\
\hline Two parents working & & & $(0.059)$ & & $(0.048)$ & $(0.049)$ \\
\hline Absolute income $X$ & & & & 0.908 & 1.034 & 0.948 \\
\hline College & & & & $(0.059)$ & $(0.068)$ & $(0.062)$ \\
\hline Absolute income $\mathrm{X}$ & & & & $0.891 *$ & 1.016 & 0.932 \\
\hline School & & & & $(0.049)$ & $(0.059)$ & $(0.054)$ \\
\hline Absolute income $\mathrm{X}$ & & & & 1.082 & $1.225^{*}$ & 1.170 \\
\hline No qualifications & & & & $(0.100)$ & $(0.120)$ & $(0.114)$ \\
\hline \multicolumn{7}{|l|}{ Goodness-of-fit } \\
\hline Log likelihood & $-22,727$ & $-22,514$ & $-22,945$ & $-22,944$ & $-22,692$ & $-22,484$ \\
\hline AIC & 45,490 & 45,064 & 45,925 & 45,924 & 45,429 & 45,014 \\
\hline
\end{tabular}

Note. ${ }^{*} \mathrm{p}<.05, * * \mathrm{p}<.01,{ }^{* * *} \mathrm{p}<.001 . \mathrm{AIC}=$ Akaike's Information Criterion 
Figure 1. Slope of the longitudinal interactions between absolute household income and children's SDQ scores by (a) Income rank, (b) Parents' work status. Standard errors are represented in the figure by the error bars attached to each column.
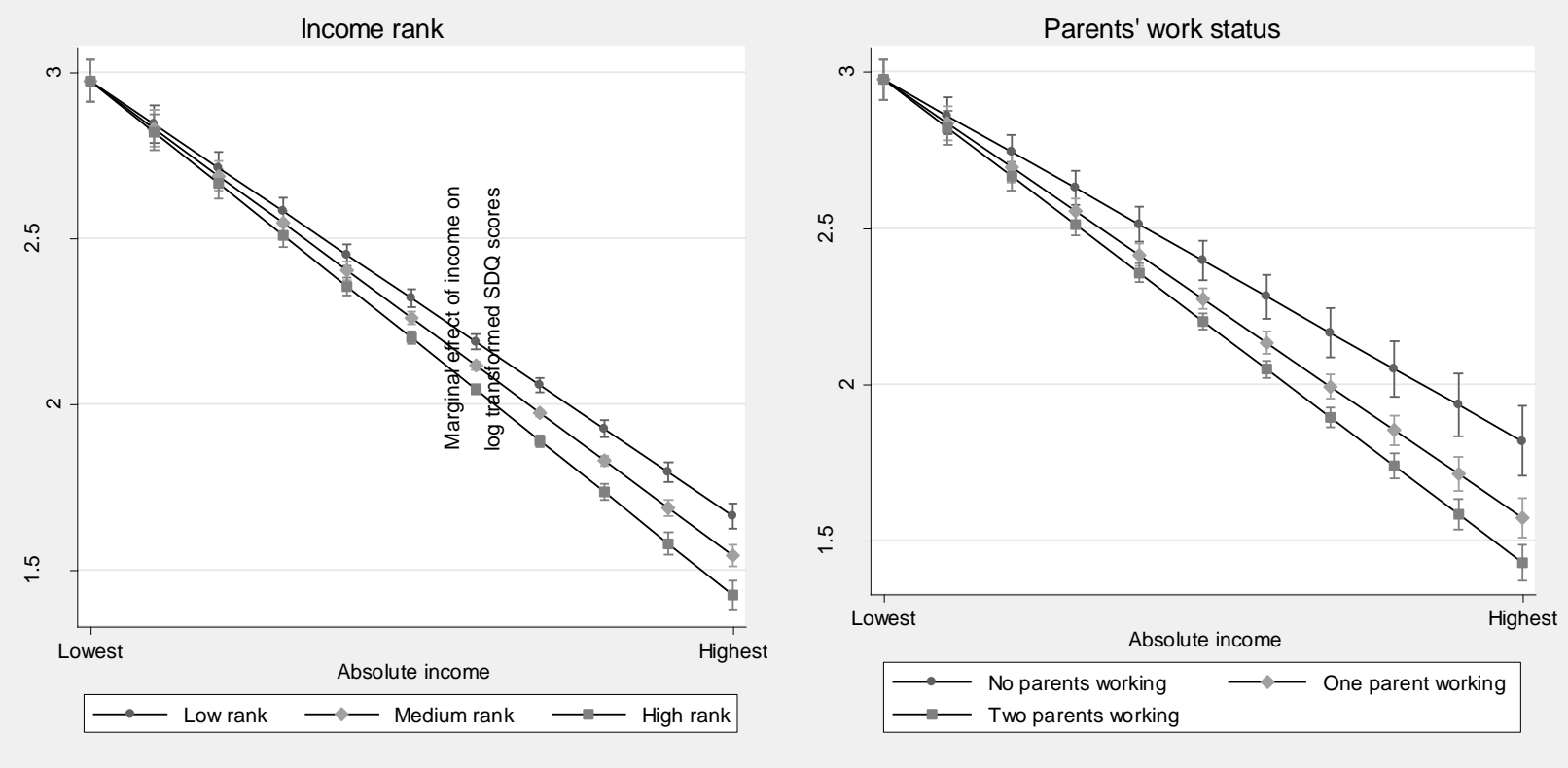

Table 6

Mean predicted $S D Q$ scores by absolute household income and income rank

\begin{tabular}{lrrrrr}
\hline \multirow{2}{*}{$\begin{array}{c}\text { Household income } \\
\text { quintile }\end{array}$} & $\begin{array}{c}\text { Mean } \\
\text { equivalized } \\
\text { absolute weekly } \\
\text { income }\end{array}$ & $\begin{array}{c}\text { Low } \\
\text { rank }\end{array}$ & $\begin{array}{c}\text { Middle } \\
\text { rank }\end{array}$ & $\begin{array}{l}\text { High } \\
\text { rank }\end{array}$ & $\begin{array}{c}\text { Percentage reduction in } \\
\text { SDQ scores between low- } \\
\text { and high-ranking children } \\
(\%)\end{array}$ \\
\hline Lowest incomes & $£ 13.16$ & 19.57 & 19.57 & 19.57 & 0.00 \\
$20^{\text {th }}$ percentile & $£ 98.75$ & 15.06 & 14.70 & 14.36 & 4.67 \\
$40^{\text {th }}$ percentile & $£ 189.86$ & 11.59 & 11.05 & 10.53 & 9.12 \\
$60^{\text {th }}$ percentile & $£ 275.47$ & 8.92 & 8.30 & 7.73 & 13.36 \\
$80^{\text {th }}$ percentile & $£ 554.89$ & 6.86 & 6.23 & 5.67 & 17.40 \\
Highest incomes & $£ 1,148.72$ & 5.28 & 4.68 & 4.16 & 21.26 \\
\hline $\begin{array}{l}\text { Percentage reduction in SDQ scores } \\
\text { between children with low and high }\end{array}$ & & & & \\
absolute income (\%) & & & & & \\
\hline
\end{tabular}

Table 7

Mean predicted SDQ scores by absolute household income and parents' working status

\begin{tabular}{|c|c|c|c|c|c|}
\hline \multirow[b]{2}{*}{$\begin{array}{l}\text { Household income } \\
\text { quintile }\end{array}$} & \multirow{2}{*}{$\begin{array}{c}\text { Mean } \\
\text { equivalized } \\
\text { absolute } \\
\text { weekly income }\end{array}$} & \multicolumn{3}{|c|}{ Predicted SDQ score } & \multirow{2}{*}{$\begin{array}{l}\text { Percentage reduction } \\
\text { in SDQ scores by } \\
\text { parents' working } \\
\text { status }(\%)\end{array}$} \\
\hline & & $\begin{array}{c}\text { No } \\
\text { parents } \\
\text { working } \\
\end{array}$ & $\begin{array}{c}\text { One } \\
\text { parent } \\
\text { working }\end{array}$ & $\begin{array}{c}\text { Two } \\
\text { parents } \\
\text { working }\end{array}$ & \\
\hline Lowest incomes & $£ 13.16$ & 19.57 & 19.57 & 19.57 & 0.00 \\
\hline $20^{\text {th }}$ percentile & $£ 98.75$ & 15.53 & 14.79 & 14.37 & 7.47 \\
\hline $40^{\text {th }}$ percentile & $£ 189.86$ & 12.32 & 11.17 & 10.55 & 14.39 \\
\hline $60^{\text {th }}$ percentile & $£ 275.47$ & 9.78 & 8.44 & 7.75 & 20.78 \\
\hline $80^{\text {th }}$ percentile & $£ 554.89$ & 7.76 & 6.38 & 5.69 & 26.70 \\
\hline Highest incomes & $£ 1,148.72$ & 6.16 & 4.82 & 4.18 & 32.18 \\
\hline $\begin{array}{l}\text { Percentage reduction } \\
\text { between children wit } \\
\text { absolute income (\%) }\end{array}$ & $\begin{array}{l}\text { SDQ scores } \\
\text { ow and high }\end{array}$ & 68.53 & 75.39 & 78.66 & \\
\hline
\end{tabular}


Table 8

Panel regression analyses of internalizing and externalizing scores predicted by exponentiated coefficients of interactions between absolute household income and measures of socioeconomic disadvantage $(n=52,956)$

\begin{tabular}{|c|c|c|c|c|}
\hline & $\begin{array}{c}\text { Model } 1 \\
\text { Internalizing }\end{array}$ & $\begin{array}{c}\text { Model } 2 \\
\text { Externalizing }\end{array}$ & $\begin{array}{c}\text { Model } 3 \\
\text { Internalizing }\end{array}$ & $\begin{array}{c}\text { Model } 4 \\
\text { Externalizing } \\
\end{array}$ \\
\hline \multicolumn{5}{|c|}{ Fixed effects (exponentiated coefficients, se) } \\
\hline Absolute income & $\begin{array}{r}0.665^{* * * *} \\
(0.058)\end{array}$ & $\begin{array}{r}0.446^{* * * *} \\
(0.034)\end{array}$ & $\begin{array}{r}0.576^{* * * *} \\
(0.051)\end{array}$ & $\begin{array}{r}0.350^{* * * *} \\
(0.027)\end{array}$ \\
\hline Distance from the mean & $\begin{array}{r}1.592 * * * \\
(0.075)\end{array}$ & $\begin{array}{r}1.756^{* * *} \\
(0.071)\end{array}$ & & \\
\hline Income rank & & & $\begin{array}{r}1.877 * * * \\
(0.087)\end{array}$ & $\begin{array}{r}2.388 * * * \\
(0.095)\end{array}$ \\
\hline No parents working & $\begin{array}{r}1.000 \\
(0)\end{array}$ & $\begin{array}{r}1.000 \\
(0)\end{array}$ & $\begin{array}{r}1.000 \\
(0)\end{array}$ & $\begin{array}{r}1.000 \\
(0)\end{array}$ \\
\hline One parent working & $\begin{array}{l}1.119^{*} \\
(0.049)\end{array}$ & $\begin{array}{r}1.126^{* *} \\
(0.043)\end{array}$ & $\begin{array}{l}1.104^{*} \\
(0.049)\end{array}$ & $\begin{array}{r}1.111^{* *} \\
(0.042)\end{array}$ \\
\hline Two parents working & $\begin{array}{r}1.174 * * \\
(0.060)\end{array}$ & $\begin{array}{r}1.232 * * * \\
(0.054)\end{array}$ & $\begin{array}{l}1.131^{*} \\
(0.058)\end{array}$ & $\begin{array}{r}1.178^{* * *} \\
(0.051)\end{array}$ \\
\hline University & $\begin{array}{r}1.000 \\
(0)\end{array}$ & $\begin{array}{r}1.000 \\
(0)\end{array}$ & $\begin{array}{r}1.000 \\
(0)\end{array}$ & $\begin{array}{r}1.000 \\
(0)\end{array}$ \\
\hline College & $\begin{array}{r}0.992 \\
(0.054)\end{array}$ & $\begin{array}{r}1.018 \\
(0.048)\end{array}$ & $\begin{array}{r}1.036 \\
(0.057)\end{array}$ & $\begin{array}{r}1.073 \\
(0.050)\end{array}$ \\
\hline School & $\begin{array}{r}0.988 \\
(0.048)\end{array}$ & $\begin{array}{r}1.013 \\
(0.042)\end{array}$ & $\begin{array}{r}1.032 \\
(0.050)\end{array}$ & $\begin{array}{r}1.067 \\
(0.044)\end{array}$ \\
\hline $\begin{array}{l}\text { No educational } \\
\text { qualifications }\end{array}$ & $\begin{array}{r}0.974 \\
(0.082) \\
\end{array}$ & $\begin{array}{r}1.039 \\
(0.075) \\
\end{array}$ & $\begin{array}{r}1.014 \\
(0.085) \\
\end{array}$ & $\begin{array}{r}1.089 \\
(0.078) \\
\end{array}$ \\
\hline \multicolumn{5}{|l|}{ Interaction effects } \\
\hline Absolute income $\mathrm{X}$ & 1.030 & $1.090 * * *$ & & \\
\hline Middle DFM & $(0.019)$ & $(0.017)$ & & \\
\hline Absolute income $\mathrm{X}$ & 0.994 & $1.089 * * *$ & & \\
\hline High DFM & $(0.024)$ & $(0.023)$ & & \\
\hline Absolute income $\mathrm{X}$ & & & $0.903 * * *$ & $0.902 * * *$ \\
\hline Middle rank & & & $(0.020)$ & $(0.017)$ \\
\hline Absolute income $\mathrm{X}$ & & & $0.815 * * *$ & $0.814 * * *$ \\
\hline High rank & & & $(0.026)$ & $(0.022)$ \\
\hline Absolute income $\mathrm{X}$ & $0.789 * *$ & $0.813^{* *}$ & $0.784 * *$ & $0.800 * *$ \\
\hline One parent working & $(0.064)$ & $(0.057)$ & $(0.064)$ & $(0.056)$ \\
\hline Absolute income $\mathrm{X}$ & $0.700 * * *$ & $0.701 * * *$ & $0.718 * * *$ & $0.717 * * *$ \\
\hline Two parents working & $(0.061)$ & $(0.052)$ & $(0.062)$ & $(0.053)$ \\
\hline Absolute income $\mathrm{X}$ & 1.004 & 1.032 & 0.940 & 0.956 \\
\hline College & $(0.078)$ & $(0.069)$ & $(0.073)$ & $(0.063)$ \\
\hline Absolute income $\mathrm{X}$ & 1.049 & 0.988 & 0.982 & 0.915 \\
\hline School & $(0.072)$ & $(0.058)$ & $(0.067)$ & $(0.053)$ \\
\hline Absolute income $\mathrm{X}$ & 1.120 & 1.179 & 1.080 & 1.134 \\
\hline No qualifications & $(0.130)$ & $(0.117)$ & $(0.125)$ & $(0.112)$ \\
\hline \multicolumn{5}{|l|}{ Goodness-of-fit } \\
\hline Log likelihood & $-31,618$ & $-23,470$ & $-31,555$ & $-23,264$ \\
\hline AIC & 63,282 & 46,986 & 63,157 & 46,573 \\
\hline
\end{tabular}

Note. ${ }^{*} \mathrm{p}<.05, * * \mathrm{p}<.01, * * * \mathrm{p}<.001$. AIC $=$ Akaike's Information Criterion 
Supplementary analyses for the manuscript "Income and Social Rank Influence UK Children's Behavioral Problems: A Longitudinal Analysis” (Ref.: MS 2015-282)

Table A1

Panel regression analyses of children's $S D Q$ scores predicted by exponentiated coefficients of absolute income, distance from mean income and income rank and interactions between income variables, boys $(n=26,925)$

\begin{tabular}{|c|c|c|c|c|c|}
\hline & Model 1 & Model 2 & Model 3 & Model 4 & Model 5 \\
\hline \multicolumn{6}{|c|}{ Fixed effects (exponentiated coefficients, se) } \\
\hline Absolute income & $\begin{array}{r}0.688^{* * * *} \\
(0.024)\end{array}$ & & & $\begin{array}{r}0.454 * * * \\
(0.023)\end{array}$ & $\begin{array}{r}0.340 * * * \\
(0.020)\end{array}$ \\
\hline $\begin{array}{l}\text { Distance from the } \\
\text { mean }\end{array}$ & & $\begin{array}{r}1.003 \\
(0.032)\end{array}$ & & $\begin{array}{r}1.666 * * * \\
(0.076)\end{array}$ & \\
\hline Income rank & & & $\begin{array}{r}1.001 \\
(0.022)\end{array}$ & & $\begin{array}{r}1.698 * * * \\
(0.062) \\
\end{array}$ \\
\hline \multicolumn{6}{|l|}{ Goodness-of-fit } \\
\hline Log likelihood & $-10,860$ & $-10,941$ & $-10,941$ & $-10,769$ & $-10,706$ \\
\hline AIC & 21,750 & 21,912 & 21,912 & 21,570 & 21,444 \\
\hline
\end{tabular}

Note. ${ }^{*} \mathrm{p}<.05,{ }^{* *} \mathrm{p}<.01,{ }^{* * *} \mathrm{p}<.001 . \mathrm{AIC}=$ Akaike's Information Criterion 
Table A2

Panel regression analyses of children's $S D Q$ scores predicted by exponentiated coefficients of interactions between absolute income and measures of socioeconomic disadvantage, boys $(n=26,925)$

Model $1 \quad$ Model $2 \quad$ Model $3 \quad$ Model $4 \quad$ Model $5 \quad$ Model 6

\begin{tabular}{|c|c|c|c|c|c|c|}
\hline \multicolumn{7}{|c|}{ Fixed effects (exponentiated coefficients, se) } \\
\hline \multirow{2}{*}{ Absolute income } & $0.437 * * *$ & $0.334 * * *$ & $0.729 * * *$ & $0.737 * * *$ & $0.536^{* * * *}$ & $0.427 * * *$ \\
\hline & $(0.025)$ & $(0.020)$ & $(0.055)$ & $(0.037)$ & $(0.054)$ & $(0.043)$ \\
\hline \multirow{2}{*}{$\begin{array}{l}\text { Distance from the } \\
\text { mean }\end{array}$} & $1.677 * * *$ & & & & $1.719 * * *$ & \\
\hline & $(0.090)$ & & & & $(0.094)$ & \\
\hline Income rank & & $\begin{array}{r}2.225 * * * \\
(0.119)\end{array}$ & & & & $\begin{array}{r}2.247 * * * \\
(0.121)\end{array}$ \\
\hline No parents working & & & $\begin{array}{r}1.000 \\
(0.000)\end{array}$ & & $\begin{array}{r}1.000 \\
(0.000)\end{array}$ & $\begin{array}{r}1.000 \\
(0.000)\end{array}$ \\
\hline One parent working & & & $\begin{array}{r}1.049 \\
(0.051)\end{array}$ & & $\begin{array}{r}1.172 * * \\
(0.059)\end{array}$ & $\begin{array}{r}1.154 * * \\
(0.058)\end{array}$ \\
\hline Two parents working & & & $\begin{array}{r}1.035 \\
(0.055)\end{array}$ & & $\begin{array}{r}1.221 * * * \\
(0.071)\end{array}$ & $\begin{array}{r}1.168 * * \\
(0.067)\end{array}$ \\
\hline University & & & & $\begin{array}{r}1.000 \\
(0.000)\end{array}$ & $\begin{array}{r}1.000 \\
(0.000)\end{array}$ & $\begin{array}{r}1.000 \\
(0.000)\end{array}$ \\
\hline College & & & & $\begin{array}{r}1.116 \\
(0.070)\end{array}$ & $\begin{array}{r}1.045 \\
(0.066)\end{array}$ & $\begin{array}{r}1.099 \\
(0.069)\end{array}$ \\
\hline School & & & & $\begin{array}{l}1.116^{*} \\
(0.061)\end{array}$ & $\begin{array}{r}1.036 \\
(0.058)\end{array}$ & $\begin{array}{r}1.088 \\
(0.061)\end{array}$ \\
\hline $\begin{array}{l}\text { No educational } \\
\text { qualifications }\end{array}$ & & & & $\begin{array}{l}1.295^{* *} \\
(0.0129)\end{array}$ & $\begin{array}{r}1.207 \\
(0.124)\end{array}$ & $\begin{array}{l}1.259 * \\
(0.128)\end{array}$ \\
\hline \multicolumn{7}{|l|}{ Interaction effects } \\
\hline Absolute income $\mathrm{X}$ & 1.036 & & & & $1.052^{*}$ & \\
\hline \multirow{2}{*}{$\begin{array}{l}\text { Middle DFM } \\
\text { Absolute income X }\end{array}$} & $(0.021)$ & & & & $(0.022)$ & \\
\hline & 1.021 & & & & 1.015 & \\
\hline High DFM & $(0.028)$ & & & & $(0.030)$ & \\
\hline Absolute income $\mathrm{X}$ & & $0.872 * * *$ & & & & $0.885 * * *$ \\
\hline Middle rank & & $(0.021)$ & & & & $(0.022)$ \\
\hline Absolute income $\mathrm{X}$ & & $0.786 * * *$ & & & & $0.806 * * *$ \\
\hline \multicolumn{2}{|l|}{ High rank } & $(0.028)$ & & & & $(0.029)$ \\
\hline \multicolumn{2}{|l|}{ Absolute income $\mathrm{X}$} & & 0.928 & & $0.747 * *$ & $0.740 * *$ \\
\hline \multicolumn{2}{|l|}{ One parent working } & & $(0.082)$ & & $(0.070)$ & $(0.069$ \\
\hline \multicolumn{2}{|l|}{ Absolute income $\mathrm{X}$} & & 0.932 & & $0.687 * * *$ & $0.706^{* * *}$ \\
\hline \multicolumn{2}{|l|}{ Two parents working } & & $(0.083)$ & & $(0.068)$ & $(0.069)$ \\
\hline \multicolumn{2}{|l|}{ Absolute income $\mathrm{X}$} & & & 0.876 & 0.987 & 0.917 \\
\hline \multicolumn{2}{|l|}{ College } & & & $(0.078)$ & $(0.089)$ & $(0.082)$ \\
\hline \multicolumn{2}{|l|}{ Absolute income $\mathrm{X}$} & & & 0.865 & 0.987 & 0.918 \\
\hline \multicolumn{2}{|l|}{ School } & & & $(0.065)$ & $(0.078)$ & $(0.072)$ \\
\hline \multicolumn{2}{|l|}{ Absolute income $\mathrm{X}$} & & & 0.982 & 1.095 & 1.057 \\
\hline No qualifications & & & & $(0.124)$ & $(0.146)$ & $(0.140)$ \\
\hline Goodness-of-fit & & & & & & \\
\hline Log likelihood & $-10,766$ & $-10,672$ & $-10,860$ & $-10,857$ & $-10,753$ & $-10,660$ \\
\hline AIC & 21,568 & 21,379 & 21,753 & 21,749 & 21,552 & 21,365 \\
\hline
\end{tabular}

Note. ${ }^{*} \mathrm{p}<.05, * * \mathrm{p}<.01,{ }^{* * *} \mathrm{p}<.001 . \mathrm{AIC}=$ Akaike's Information Criterion 
Table A3

Panel regression analyses of internalizing and externalizing scores predicted by exponentiated coefficients of interactions between absolute income and measures of socioeconomic disadvantage, boys $(n=26,925)$

\begin{tabular}{|c|c|c|c|c|}
\hline & $\begin{array}{c}\text { Model 1 } \\
\text { Internalizing }\end{array}$ & $\begin{array}{c}\text { Model } 2 \\
\text { Internalizing }\end{array}$ & $\begin{array}{c}\text { Model } 3 \\
\text { Externalizing } \\
\end{array}$ & $\begin{array}{c}\text { Model } 4 \\
\text { Externalizing } \\
\end{array}$ \\
\hline \multicolumn{5}{|c|}{ Fixed effects (exponentiated coefficients, se) } \\
\hline Absolute income & $\begin{array}{r}0.653 * * * \\
(0.080)\end{array}$ & $\begin{array}{r}0.541 * * * \\
(0.067)\end{array}$ & $\begin{array}{r}0.549 * * * \\
(0.055)\end{array}$ & $\begin{array}{r}0.445 * * * \\
(0.046)\end{array}$ \\
\hline Distance from the mean & $\begin{array}{r}1.552 * * * \\
(0.104)\end{array}$ & & $\begin{array}{r}1.592 * * * \\
(0.088)\end{array}$ & \\
\hline Income rank & & $\begin{array}{r}1.941 * * * \\
(0.128)\end{array}$ & & $\begin{array}{r}2.057 * * * \\
(0.112)\end{array}$ \\
\hline No parents working & $\begin{array}{r}1.000 \\
(0.000)\end{array}$ & $\begin{array}{r}1.000 \\
(0.000)\end{array}$ & $\begin{array}{r}1.000 \\
(0.000)\end{array}$ & $\begin{array}{r}1.000 \\
(0.000)\end{array}$ \\
\hline One parent working & $\begin{array}{l}1.139^{*} \\
(0.071)\end{array}$ & $\begin{array}{r}1.126 \\
(0.070)\end{array}$ & $\begin{array}{r}1.165^{* * *} \\
(0.060)\end{array}$ & $\begin{array}{r}1.151^{* * *} \\
(0.059)\end{array}$ \\
\hline Two parents working & $\begin{array}{r}1.100 \\
(0.078)\end{array}$ & $\begin{array}{r}1.062 \\
(0.075)\end{array}$ & $\begin{array}{r}1.192 * * \\
(0.070)\end{array}$ & $\begin{array}{l}1.148^{*} \\
(0.067)\end{array}$ \\
\hline University & $\begin{array}{r}1.000 \\
(0.000)\end{array}$ & $\begin{array}{r}1.000 \\
(0.000)\end{array}$ & $\begin{array}{r}1.000 \\
(0.000)\end{array}$ & $\begin{array}{r}1.000 \\
(0.000)\end{array}$ \\
\hline College & $\begin{array}{r}1.046 \\
(0.081)\end{array}$ & $\begin{array}{r}1.090 \\
(0.084)\end{array}$ & $\begin{array}{r}1.038 \\
(0.066)\end{array}$ & $\begin{array}{r}1.084 \\
(0.069)\end{array}$ \\
\hline School & $\begin{array}{r}1.001 \\
(0.069)\end{array}$ & $\begin{array}{r}1.041 \\
(0.072)\end{array}$ & $\begin{array}{r}1.061 \\
(0.060)\end{array}$ & $\begin{array}{r}1.107 \\
(0.063)\end{array}$ \\
\hline No qualifications & $\begin{array}{r}1.024 \\
(0.129) \\
\end{array}$ & $\begin{array}{r}1.058 \\
(0.133) \\
\end{array}$ & $\begin{array}{r}1.254^{*} \\
(0.130)\end{array}$ & $\begin{array}{r}1.299 * \\
(0.134) \\
\end{array}$ \\
\hline \multicolumn{5}{|l|}{ Interaction effects } \\
\hline Absolute income X & 1.028 & & $1.058^{* *}$ & \\
\hline Middle DFM & $(0.026)$ & & $(0.022)$ & \\
\hline Absolute income X & 0.994 & & $1.078^{* *}$ & \\
\hline High DFM & $(0.035)$ & & $(0.031)$ & \\
\hline Absolute income X & & $0.891 * * *$ & & $0.906^{* * *}$ \\
\hline Middle rank & & $(0.027)$ & & $(0.023)$ \\
\hline Absolute income X & & $0.799 * * *$ & & $0.848 * * *$ \\
\hline High rank & & $(0.035)$ & & $(0.031)$ \\
\hline Absolute income X & $0.749^{*}$ & $0.743^{* *}$ & $0.771 * *$ & $0.763 * *$ \\
\hline One parent working & $(0.086)$ & $(0.085)$ & $(0.073)$ & $(0.072)$ \\
\hline Absolute income X & $0.748^{*}$ & $0.765^{*}$ & $0.743 * *$ & $0.760 * *$ \\
\hline Two parents working & $(0.090)$ & $(0.092)$ & $(0.074)$ & $(0.075)$ \\
\hline Absolute income X & 0.973 & 0.916 & 0.998 & 0.937 \\
\hline College & $(0.107)$ & $(0.100)$ & $(0.091)$ & $(0.084)$ \\
\hline Absolute income X & 1.048 & 0.989 & 0.937 & 0.881 \\
\hline School & $(0.102)$ & $(0.095)$ & $(0.075)$ & $(0.070)$ \\
\hline Absolute income X & 1.064 & 1.034 & 1.084 & 1.053 \\
\hline No qualifications & $(0.174)$ & $(0.169)$ & $(0.146)$ & $(0.141)$ \\
\hline \multicolumn{5}{|l|}{ Goodness-of-fit } \\
\hline Log likelihood & $-16,252$ & $-16,209$ & $-11,039$ & $-10,962$ \\
\hline AIC & 32,549 & 32,465 & 22,124 & 21,970 \\
\hline
\end{tabular}

Note. ${ }^{*} \mathrm{p}<.05, * * \mathrm{p}<.01, * * * \mathrm{p}<.001 . \mathrm{AIC}=$ Akaike's Information Criterion 
Table A4

Panel regression analyses of children's $S D Q$ scores predicted by exponentiated coefficients of absolute income, distance from mean income and income rank and interactions between income variables, girls $(n=26,033)$

\begin{tabular}{|c|c|c|c|c|c|}
\hline & Model 1 & Model 2 & Model 3 & Model 4 & Model 5 \\
\hline \multicolumn{6}{|c|}{ Fixed effects (exponentiated coefficients, se) } \\
\hline Absolute income & $\begin{array}{r}0.621 * * * \\
(0.024)\end{array}$ & & & $\begin{array}{r}0.376 * * * \\
(0.021)\end{array}$ & $\begin{array}{r}0.264 * * * \\
(0.017)\end{array}$ \\
\hline $\begin{array}{l}\text { Distance from the } \\
\text { mean }\end{array}$ & & $\begin{array}{r}0.991 \\
(0.034)\end{array}$ & & $\begin{array}{r}1.841 * * * \\
(0.090)\end{array}$ & \\
\hline Income rank & & & $\begin{array}{r}0.997 \\
(0.023)\end{array}$ & & $\begin{array}{r}1.909 * * * \\
(0.075) \\
\end{array}$ \\
\hline \multicolumn{6}{|l|}{ Goodness-of-fit } \\
\hline Log likelihood & $-12,022$ & $-12,132$ & $-12,132$ & $-11,909$ & $-11,825$ \\
\hline AIC & 24,074 & 24,294 & 24,292 & 23,849 & 23,682 \\
\hline
\end{tabular}

Note. ${ }^{*} \mathrm{p}<.05, * * \mathrm{p}<.01, * * * \mathrm{p}<.001 . \mathrm{AIC}=$ Akaike's Information Criterion 
Table A5

Panel regression analyses of children's $S D Q$ scores predicted by exponentiated coefficients of interactions between absolute income and measures of socioeconomic disadvantage, girls $(n=26,033)$

Model $1 \quad$ Model $2 \quad$ Model $3 \quad$ Model $4 \quad$ Model $5 \quad$ Model 6

\begin{tabular}{|c|c|c|c|c|c|c|}
\hline \multicolumn{7}{|c|}{ Fixed effects (exponentiated coefficients, se) } \\
\hline \multirow{2}{*}{ Absolute income } & $0.344 * * *$ & $0.254 * * *$ & $0.632 * * *$ & $0.634 * * *$ & $0.381 * * *$ & $0.302 * * *$ \\
\hline & $(0.021)$ & $(0.016)$ & $(0.052)$ & $(0.035)$ & $(0.042)$ & $(0.034)$ \\
\hline \multirow{2}{*}{$\begin{array}{l}\text { Distance from the } \\
\text { mean }\end{array}$} & $1.934 * * *$ & & & & $2.023 * * *$ & \\
\hline & $(0.109)$ & & & & $(0.117)$ & \\
\hline Income rank & & $\begin{array}{r}2.690 * * * \\
(0.153)\end{array}$ & & & & $\begin{array}{r}2.721 * * * \\
(0.155)\end{array}$ \\
\hline No parents working & & & $\begin{array}{r}1.000 \\
(0)\end{array}$ & & $\begin{array}{r}1.000 \\
(0)\end{array}$ & $\begin{array}{r}1.000 \\
(0)\end{array}$ \\
\hline One parent working & & & $\begin{array}{r}0.970 \\
(0.051)\end{array}$ & & $\begin{array}{r}1.089 \\
(0.060)\end{array}$ & $\begin{array}{r}1.071 \\
(0.058)\end{array}$ \\
\hline Two parents working & & & $\begin{array}{r}1.095 \\
(0.064)\end{array}$ & & $\begin{array}{r}1.291 * * * \\
(0.083)\end{array}$ & $\begin{array}{r}1.222 * * \\
(0.078)\end{array}$ \\
\hline University & & & & $\begin{array}{r}1.000 \\
(0)\end{array}$ & $\begin{array}{r}1.000 \\
(0)\end{array}$ & $\begin{array}{r}1.000 \\
(0)\end{array}$ \\
\hline College & & & & $\begin{array}{r}1.041 \\
(0.070)\end{array}$ & $\begin{array}{r}0.961 \\
(0.065)\end{array}$ & $\begin{array}{r}1.027 \\
(0.069)\end{array}$ \\
\hline School & & & & $\begin{array}{r}1.043 \\
(0.060)\end{array}$ & $\begin{array}{r}0.973 \\
(0.058)\end{array}$ & $\begin{array}{r}1.042 \\
(0.062)\end{array}$ \\
\hline No qualifications & & & & $\begin{array}{r}0.956 \\
(0.091) \\
\end{array}$ & $\begin{array}{r}0.876 \\
(0.087) \\
\end{array}$ & $\begin{array}{r}0.934 \\
(0.092) \\
\end{array}$ \\
\hline \multicolumn{7}{|l|}{ Interaction effects } \\
\hline \multirow{4}{*}{$\begin{array}{l}\text { Absolute income X } \\
\text { Middle DFM } \\
\text { Absolute income X } \\
\text { High DFM }\end{array}$} & $1.085 * * *$ & & & & $1.101 * * *$ & \\
\hline & $(0.024)$ & & & & $(0.025)$ & \\
\hline & 1.024 & & & & $1.063^{*}$ & \\
\hline & $(0.030)$ & & & & $(0.033)$ & \\
\hline Absolute income $\mathrm{X}$ & & $0.876^{* * *}$ & & & & $0.889 * * *$ \\
\hline Middle rank & & $(0.023)$ & & & & $(0.024)$ \\
\hline Absolute income $\mathrm{X}$ & & $0.742 * * *$ & & & & $0.769 * * *$ \\
\hline \multicolumn{2}{|l|}{ High rank } & $(0.028)$ & & & & $(0.030)$ \\
\hline \multicolumn{2}{|l|}{ Absolute income $\mathrm{X}$} & & 1.086 & & 0.854 & 0.838 \\
\hline \multicolumn{2}{|l|}{ One parent working } & & $(0.104)$ & & $(0.087)$ & $(0.085)$ \\
\hline \multicolumn{2}{|l|}{ Absolute income X } & & 0.879 & & $0.637 * * *$ & $0.655 * * *$ \\
\hline \multicolumn{2}{|l|}{ Two parents working } & & $(0.086)$ & & $(0.070)$ & $(0.071)$ \\
\hline \multicolumn{2}{|l|}{ Absolute income $\mathrm{X}$} & & & 0.946 & 1.090 & 0.987 \\
\hline \multicolumn{2}{|l|}{ College } & & & $(0.091)$ & $(0.106)$ & $(0.095)$ \\
\hline \multicolumn{2}{|l|}{ Absolute income $\mathrm{X}$} & & & 0.921 & 1.045 & 0.944 \\
\hline \multicolumn{2}{|l|}{ School } & & & $(0.075)$ & $(0.089)$ & $(0.080)$ \\
\hline \multicolumn{2}{|l|}{ Absolute income $\mathrm{X}$} & & & 1.187 & $1.369^{*}$ & 1.291 \\
\hline \multicolumn{2}{|l|}{ No qualifications } & & & $(0.161)$ & $(0.198)$ & $(0.185)$ \\
\hline \multicolumn{7}{|l|}{ Goodness-of-fit } \\
\hline Log likelihood & $-11,889$ & $-11,770$ & $-12,015$ & $-12,020$ & $-11,863$ & $-11,749$ \\
\hline AIC & 23,815 & 23,575 & 24,065 & 24,075 & 23,772 & 23,543 \\
\hline
\end{tabular}

Note. ${ }^{*} \mathrm{p}<.05, * * \mathrm{p}<.01, * * * \mathrm{p}<.001 . \mathrm{AIC}=$ Akaike's Information Criterion. 
Table A6

Panel regression analyses of internalizing and externalizing scores predicted by exponentiated coefficients of interactions between absolute income and measures of socioeconomic disadvantage, girls $(n=26,033)$

\begin{tabular}{|c|c|c|c|c|}
\hline & $\begin{array}{c}\text { Model 1 } \\
\text { Internalizing }\end{array}$ & $\begin{array}{c}\text { Model } 2 \\
\text { Internalizing }\end{array}$ & $\begin{array}{c}\text { Model } 3 \\
\text { Externalizing }\end{array}$ & $\begin{array}{c}\text { Model } 4 \\
\text { Externalizing }\end{array}$ \\
\hline \multicolumn{5}{|c|}{ Fixed effects (exponentiated coefficients, se) } \\
\hline \multirow{2}{*}{ Absolute income } & $0.694 * *$ & $0.629 * * *$ & $0.349 * * *$ & $0.267 * * *$ \\
\hline & $(0.087)$ & $(0.080)$ & $(0.039)$ & $(0.030)$ \\
\hline \multirow{2}{*}{ Distance from the mean } & $1.627 * * *$ & & $1.951 * * *$ & \\
\hline & $(0.107)$ & & $(0.114)$ & \\
\hline \multirow{2}{*}{ Income rank } & & $1.809 * * *$ & & $2.796^{* * *}$ \\
\hline & & $(0.118)$ & & $(0.162)$ \\
\hline \multirow{2}{*}{ No parents working } & 1.000 & 1.000 & 1.000 & 1.000 \\
\hline & (0) & (0) & (0) & $(0)$ \\
\hline \multirow{2}{*}{ One parent working } & 1.101 & 1.087 & 1.077 & 1.061 \\
\hline & $(0.069)$ & $(0.068)$ & $(0.060)$ & $(0.059)$ \\
\hline \multirow{2}{*}{ Two parents working } & $1.226^{* *}$ & $1.219^{* *}$ & $1.264 * * *$ & $1.201 * *$ \\
\hline & $(0.093)$ & $(0.089)$ & $(0.083)$ & $(0.078)$ \\
\hline \multirow{2}{*}{ University } & 1.000 & 1.000 & 1.000 & 1.000 \\
\hline & $(0)$ & (0) & (0) & $(0)$ \\
\hline \multirow{2}{*}{ College } & 0.949 & 0.995 & 0.983 & 1.045 \\
\hline & $(0.074)$ & $(0.077)$ & $(0.068)$ & $(0.071)$ \\
\hline \multirow{2}{*}{ School } & 0.980 & 1.029 & 0.965 & 1.028 \\
\hline & $(0.067)$ & $(0.070)$ & $(0.059)$ & $(0.062)$ \\
\hline \multirow{2}{*}{ No qualifications } & 0.946 & 0.991 & 0.885 & 0.939 \\
\hline & $(0.107)$ & $(0.112)$ & $(0.089)$ & $(0.094)$ \\
\hline \multicolumn{5}{|l|}{ Interaction effects } \\
\hline Absolute income $\mathrm{X}$ & 1.032 & & $1.124 * * *$ & \\
\hline Middle DFM & $(0.027)$ & & $(0.026)$ & \\
\hline Absolute income $\mathrm{X}$ & 0.995 & & $1.101 * *$ & \\
\hline High DFM & $(0.035)$ & & $(0.034)$ & \\
\hline Absolute income $\mathrm{X}$ & & $0.915^{* *}$ & & $0.899 * * *$ \\
\hline Middle rank & & $(0.028)$ & & $(0.024)$ \\
\hline Absolute income $\mathrm{X}$ & & $0.834 * * *$ & & $0.780 * * *$ \\
\hline High rank & & $(0.037)$ & & $(0.031)$ \\
\hline Absolute income $\mathrm{X}$ & 0.827 & 0.823 & 0.877 & 0.856 \\
\hline One parent working & $(0.096)$ & $(0.095)$ & $(0.090)$ & $(0.088)$ \\
\hline Absolute income $\mathrm{X}$ & $0.644 * * *$ & $0.661 * * *$ & $0.672 * * *$ & $0.686^{* * *}$ \\
\hline Two parents working & $(0.080)$ & $(0.082)$ & $(0.075)$ & $(0.076)$ \\
\hline Absolute income $\mathrm{X}$ & 1.023 & 0.951 & 1.086 & 0.992 \\
\hline College & $(0.113)$ & $(0.105)$ & $(0.107)$ & $(0.097)$ \\
\hline Absolute income $\mathrm{X}$ & 1.040 & 0.965 & 1.042 & 0.949 \\
\hline School & $(0.101)$ & $(0.093)$ & $(0.090)$ & $(0.081)$ \\
\hline Absolute income $\mathrm{X}$ & 1.158 & 1.106 & 1.295 & 1.231 \\
\hline No qualifications & $(0.191)$ & $(0.182)$ & $(0.190)$ & $(0.179)$ \\
\hline \multicolumn{5}{|l|}{ Goodness-of-fit } \\
\hline Log likelihood & $-15,331$ & $-15,311$ & $-12,275$ & $-12,142$ \\
\hline AIC & 30,708 & 30,668 & 24,597 & 23,440 \\
\hline
\end{tabular}

Note. ${ }^{*} \mathrm{p}<.05, * * \mathrm{p}<.01, * * * \mathrm{p}<.001 . \mathrm{AIC}=$ Akaike's Information Criterion 
Table A7

Poisson count models of children's $S D Q$ scores predicted by exponentiated coefficients of absolute income, distance from mean income and income rank and interactions between income variables $(n=52,958)$

\begin{tabular}{|c|c|c|c|c|c|}
\hline & Model 1 & Model 2 & Model 3 & Model 4 & Model 5 \\
\hline \multicolumn{6}{|c|}{ Fixed effects (exponentiated coefficients, se) } \\
\hline Absolute income & $\begin{array}{r}0.704 * * * \\
(0.018)\end{array}$ & & & $\begin{array}{r}0.473 * * * \\
(0.018)\end{array}$ & $\begin{array}{r}0.372 * * * \\
(0.016)\end{array}$ \\
\hline $\begin{array}{l}\text { Distance from the } \\
\text { mean }\end{array}$ & & $\begin{array}{r}1.013 \\
(0.026)\end{array}$ & & $\begin{array}{r}1.713 * * * \\
(0.062)\end{array}$ & \\
\hline Income rank & & & $\begin{array}{r}1.008 \\
(0.017) \\
\end{array}$ & & $\begin{array}{r}1.663 * * * \\
(0.045)\end{array}$ \\
\hline \multicolumn{6}{|l|}{ Goodness-of-fit } \\
\hline Log likelihood & $-67,342$ & $-67,433$ & $-67,433$ & $-67,232$ & $-67,167$ \\
\hline AIC & 134,711 & 134,894 & 134,894 & 134,495 & 134,365 \\
\hline
\end{tabular}

Note. ${ }^{*} \mathrm{p}<.05,{ }^{*} \mathrm{p}<.01,{ }^{* * *} \mathrm{p}<.001 . \mathrm{AIC}=$ Akaike's Information Criterion 
Table A8

Poisson count models of children's $S D Q$ scores predicted by exponentiated coefficients of interactions between absolute income and measures of socioeconomic disadvantage $(n=52,958)$

\begin{tabular}{|c|c|c|c|c|c|c|}
\hline & Model 1 & Model 2 & Model 3 & Model 4 & Model 5 & Model 6 \\
\hline \multicolumn{7}{|c|}{ Fixed effects (exponentiated coefficients, se) } \\
\hline Absolute income & $\begin{array}{r}0.461 * * * \\
(0.018)\end{array}$ & $\begin{array}{r}0.355^{* * *} * \\
(0.015)\end{array}$ & $\begin{array}{r}0.747 * * * \\
(0.037)\end{array}$ & $\begin{array}{r}0.714 * * * \\
(0.028)\end{array}$ & $\begin{array}{r}0.800 * * * \\
(0.035)\end{array}$ & $\begin{array}{r}0.405 * * * \\
(0.029)\end{array}$ \\
\hline $\begin{array}{l}\text { Distance from the } \\
\text { mean }\end{array}$ & $\begin{array}{r}1.842 * * * \\
(0.081)\end{array}$ & & & & $\begin{array}{r}1.910 * * * \\
(0.085)\end{array}$ & \\
\hline Income rank & & $\begin{array}{r}2.299 * * * \\
(0.093)\end{array}$ & & & & $\begin{array}{r}2.334 * * * \\
(0.095)\end{array}$ \\
\hline No parents working & & & $\begin{array}{r}1.000 \\
(0)\end{array}$ & & $\begin{array}{r}1.000 \\
(0)\end{array}$ & $\begin{array}{r}1.000 \\
(0)\end{array}$ \\
\hline One parent working & & & $\begin{array}{r}1.008 \\
(0.033)\end{array}$ & & $\begin{array}{l}1.089 * \\
(0.037)\end{array}$ & $\begin{array}{l}1.079 * \\
(0.037)\end{array}$ \\
\hline Two parents working & & & $\begin{array}{r}1.076 \\
(0.041)\end{array}$ & & $\begin{array}{r}1.215 * * * \\
(0.050)\end{array}$ & $\begin{array}{r}1.173 * * * \\
(0.049)\end{array}$ \\
\hline University & & & & $\begin{array}{r}1.000 \\
(0)\end{array}$ & $\begin{array}{r}1.000 \\
(0)\end{array}$ & $\begin{array}{r}1.000 \\
(0)\end{array}$ \\
\hline College & & & & $\begin{array}{r}1.052 \\
(0.048\end{array}$ & $\begin{array}{r}0.995 \\
(0.046)\end{array}$ & $\begin{array}{r}1.039 \\
(0.048)\end{array}$ \\
\hline School & & & & $\begin{array}{r}1.027 \\
(0.040)\end{array}$ & $\begin{array}{r}0.971 \\
(0.039)\end{array}$ & $\begin{array}{r}1.014 \\
(0.040)\end{array}$ \\
\hline $\begin{array}{l}\text { No educational } \\
\text { qualifications }\end{array}$ & & & & $\begin{array}{r}1.018 \\
(0.064)\end{array}$ & $\begin{array}{r}0.968 \\
(0.063)\end{array}$ & $\begin{array}{r}1.006 \\
(0.065)\end{array}$ \\
\hline \multicolumn{7}{|l|}{ Interaction effects } \\
\hline Absolute income $X$ & 1.020 & & & & $1.038 *$ & \\
\hline Middle DFM & $(0.015)$ & & & & $(0.016)$ & \\
\hline Absolute income $\mathrm{X}$ & 0.968 & & & & 1.007 & \\
\hline High DFM & $(0.020)$ & & & & $(0.022)$ & \\
\hline Absolute income $\mathrm{X}$ & & $0.860 * * *$ & & & & $0.874 * * *$ \\
\hline Middle rank & & $(0.016)$ & & & & $(0.016)$ \\
\hline Absolute income $\mathrm{X}$ & & $0.752 * * *$ & & & & $0.781 * * *$ \\
\hline High rank & & $(0.020)$ & & & & $(0.021)$ \\
\hline Absolute income $\mathrm{X}$ & & & 0.978 & & $0.836^{* *}$ & $0.816^{*}$ \\
\hline One parent working & & & $(0.059)$ & & $(0.053)$ & $(0.052)$ \\
\hline Absolute income X & & & $0.860^{*}$ & & $0.680 * * *$ & $0.687 * * *$ \\
\hline Two parents working & & & $(0.054)$ & & $(0.048)$ & $(0.048)$ \\
\hline Absolute income X & & & & 0.926 & 1.029 & 0.962 \\
\hline College & & & & $(0.061)$ & $(0.069)$ & $(0.064)$ \\
\hline Absolute income $\mathrm{X}$ & & & & 0.942 & 1.046 & 0.983 \\
\hline School & & & & $(0.052)$ & $(0.060)$ & $(0.056)$ \\
\hline Absolute income $\mathrm{X}$ & & & & $1.198^{*}$ & $1.293 * * *$ & $1.264 * *$ \\
\hline No qualifications & & & & $(0.099)$ & $(0.114)$ & $(0.111)$ \\
\hline \multicolumn{7}{|l|}{ Goodness-of-fit } \\
\hline Log likelihood & -67223 & -67108 & -67337 & -67337 & -67196 & -67083 \\
\hline AIC & $-134,480$ & $-134,249$ & $-134,706$ & $-134,707$ & $-134,436$ & $-134,209$ \\
\hline
\end{tabular}


Table A9

Poisson count models of internalizing and externalizing scores predicted by exponentiated coefficients of interactions between absolute income and measures of socioeconomic disadvantage $(n=52,958)$

\begin{tabular}{|c|c|c|c|c|}
\hline & $\begin{array}{c}\text { Model 1 } \\
\text { Internalizing }\end{array}$ & $\begin{array}{c}\text { Model } 2 \\
\text { Internalizing }\end{array}$ & $\begin{array}{c}\text { Model } 3 \\
\text { Externalizing }\end{array}$ & $\begin{array}{c}\text { Model } 4 \\
\text { Externalizing }\end{array}$ \\
\hline \multicolumn{5}{|c|}{ Fixed effects (exponentiated coefficients, se) } \\
\hline Absolute income & $\begin{array}{r}0.787 * * \\
(0.064)\end{array}$ & $\begin{array}{r}0.737 * * * \\
(0.06)\end{array}$ & $\begin{array}{r}0.408 * * * \\
(0.029)\end{array}$ & $\begin{array}{r}0.320 * * * \\
(0.023)\end{array}$ \\
\hline Distance from the mean & $\begin{array}{r}1.177 * * \\
(0.060)\end{array}$ & & $\begin{array}{r}1.492 * * * \\
(0.068)\end{array}$ & \\
\hline Income rank & & $\begin{array}{r}1.288 * * * \\
(0.060)\end{array}$ & & $\begin{array}{r}2.097 * * * \\
(0.088)\end{array}$ \\
\hline No parents working & $\begin{array}{r}1.000 \\
(0)\end{array}$ & $\begin{array}{r}1.000 \\
(0)\end{array}$ & $\begin{array}{r}1.000 \\
(0)\end{array}$ & $\begin{array}{r}1.000 \\
(0)\end{array}$ \\
\hline One parent working & $\begin{array}{r}1.039 \\
(0.041)\end{array}$ & $\begin{array}{r}1.027 \\
(0.041)\end{array}$ & $\begin{array}{r}1.099 * * \\
(0.039)\end{array}$ & $\begin{array}{l}1.071 \% \\
(0.038)\end{array}$ \\
\hline Two parents working & $\begin{array}{r}1.012 \\
(0.049)\end{array}$ & $\begin{array}{r}0.990 \\
(0.047)\end{array}$ & $\begin{array}{r}1.086 \\
(0.046)\end{array}$ & $\begin{array}{r}1.029 \\
(0.043)\end{array}$ \\
\hline University & $\begin{array}{r}1.000 \\
(0)\end{array}$ & $\begin{array}{r}1.000 \\
(0)\end{array}$ & $\begin{array}{r}1.000 \\
(0)\end{array}$ & $\begin{array}{r}1.000 \\
(0)\end{array}$ \\
\hline College & $\begin{array}{l}0.899 * \\
(0.038\end{array}$ & $\begin{array}{l}0.915^{*} \\
(0.039)\end{array}$ & $\begin{array}{r}0.898^{* *} \\
(0.033)\end{array}$ & $\begin{array}{r}0.935 \\
(0.035)\end{array}$ \\
\hline School & $\begin{array}{r}0.974 \\
(0.035)\end{array}$ & $\begin{array}{r}0.991 \\
(0.035)\end{array}$ & $\begin{array}{l}0.936^{*} \\
(0.030)\end{array}$ & $\begin{array}{r}0.975 \\
(0.031)\end{array}$ \\
\hline No qualifications & $\begin{array}{r}0.934 \\
(0.049) \\
\end{array}$ & $\begin{array}{r}0.951 \\
(0.050) \\
\end{array}$ & $\begin{array}{r}0.962 \\
(0.045) \\
\end{array}$ & $\begin{array}{r}1.001 \\
(0.047) \\
\end{array}$ \\
\hline \multicolumn{5}{|l|}{ Interaction effects } \\
\hline Absolute income $\mathrm{X}$ & 0.984 & & $1.067 * * *$ & \\
\hline Middle DFM & $(0.017)$ & & $(0.016)$ & \\
\hline Absolute income $\mathrm{X}$ & $0.915 * * *$ & & 1.021 & \\
\hline High DFM & $(0.022)$ & & $(0.022)$ & \\
\hline Absolute income $\mathrm{X}$ & & $0.922 * * *$ & & $0.880 * * *$ \\
\hline Middle rank & & $(0.020)$ & & $(0.017)$ \\
\hline Absolute income $\mathrm{X}$ & & $0.828 * * *$ & & $0.753 * * *$ \\
\hline High rank & & $(0.027)$ & & $(0.022)$ \\
\hline Absolute income $\mathrm{X}$ & $0.803 * * *$ & $0.814 * *$ & $0.751 * * *$ & $0.765 * * *$ \\
\hline One parent working & $(0.060)$ & $(0.061)$ & $(0.050)$ & $(0.050)$ \\
\hline Absolute income $\mathrm{X}$ & $0.709 * * *$ & $0.726 * * *$ & $0.711 * * *$ & $0.747 * * *$ \\
\hline Two parents working & $(0.059)$ & $(0.060)$ & $(0.052)$ & $(0.054)$ \\
\hline Absolute income $\mathrm{X}$ & $1.219 * *$ & $1.189 * *$ & $1.341 * * *$ & $1.263 * * *$ \\
\hline College & $(0.079)$ & $(0.076)$ & $(0.075)$ & $(0.070)$ \\
\hline Absolute income $\mathrm{X}$ & $1.166^{* *}$ & $1.138 *$ & $1.369 * * *$ & $1.293 * * *$ \\
\hline School & $(0.066)$ & $(0.063)$ & $(0.067)$ & $(0.063)$ \\
\hline Absolute income $\mathrm{X}$ & $1.524 * * *$ & $1.488 * * *$ & $1.519 * * *$ & $1.437 * * *$ \\
\hline No qualifications & $(0.147)$ & $(0.143)$ & $(0.130)$ & $(0.122)$ \\
\hline \multicolumn{5}{|l|}{ Goodness-of-fit } \\
\hline Log likelihood & $-99,673$ & $-99,663$ & $-108,647$ & $-108,531$ \\
\hline AIC & 199,409 & 199,390 & 217,359 & 217,125 \\
\hline
\end{tabular}

Note. ${ }^{*} \mathrm{p}<.05, * * \mathrm{p}<.01, * * * \mathrm{p}<.001$. AIC $=$ Akaike's Information Criterion. 
Table A10

Panel regression analyses of children's $S D Q$ scores predicted by exponentiated coefficients of Yitzhaki income $(n=52,958)$

\begin{tabular}{|c|c|c|c|c|c|c|}
\hline & Model 1 & Model 2 & Model 3 & Model 4 & $\begin{array}{c}\text { Model } 5 \\
\text { Internalizing }\end{array}$ & $\begin{array}{c}\text { Model } \\
\text { Externalizing }\end{array}$ \\
\hline \multicolumn{7}{|c|}{ Fixed effects (exponentiated coefficients, se) } \\
\hline Absolute income & & $\begin{array}{r}0.209 * * * \\
(0.010)\end{array}$ & $\begin{array}{r}0.185 * * * \\
(0.010)\end{array}$ & $\begin{array}{r}0.220 * * * \\
(0.018)\end{array}$ & $\begin{array}{r}0.375 * * * \\
(0.037)\end{array}$ & $\begin{array}{r}0.226 * * * \\
(0.019)\end{array}$ \\
\hline Yitzhaki income & $\begin{array}{r}0.993 \\
(0.019)\end{array}$ & $\begin{array}{r}0.383 * * * \\
(0.014)\end{array}$ & $\begin{array}{r}0.328 * * * \\
(0.014)\end{array}$ & $\begin{array}{r}0.328 * * * \\
(0.014)\end{array}$ & $\begin{array}{r}0.441^{* * *} * \\
(0.022)\end{array}$ & $\begin{array}{r}0.347 * * * \\
(0.015)\end{array}$ \\
\hline $\begin{array}{l}\text { No parents } \\
\text { working }\end{array}$ & & & & $\begin{array}{r}1.000 \\
(0)\end{array}$ & $\begin{array}{r}1.000 \\
(0)\end{array}$ & $\begin{array}{r}1.000 \\
(0)\end{array}$ \\
\hline One parent & & & & 1.032 & 1.046 & 1.029 \\
\hline working & & & & $(0.038)$ & $(0.046)$ & $(0.039)$ \\
\hline Two parents & & & & 1.024 & 1.013 & 1.013 \\
\hline working & & & & $(0.044)$ & $(0.052)$ & $(0.044)$ \\
\hline University & & & & $\begin{array}{r}1.000 \\
(0)\end{array}$ & $\begin{array}{r}1.000 \\
(0)\end{array}$ & $\begin{array}{r}1.000 \\
(0)\end{array}$ \\
\hline College & & & & $\begin{array}{r}1.131 * * \\
(0.052)\end{array}$ & $\begin{array}{r}1.082 \\
(0.059)\end{array}$ & $\begin{array}{r}1.135^{* *} \\
(0.053)\end{array}$ \\
\hline School & & & & $\begin{array}{r}1.148 * * * \\
(0.047)\end{array}$ & $\begin{array}{r}1.090 \\
(0.053)\end{array}$ & $\begin{array}{r}1.147 * * * \\
(0.047)\end{array}$ \\
\hline $\begin{array}{l}\text { No educational } \\
\text { qualifications }\end{array}$ & & & & $\begin{array}{l}1.171^{*} \\
(0.082) \\
\end{array}$ & $\begin{array}{r}1.084 \\
(0.090) \\
\end{array}$ & $\begin{array}{r}1.191 * \\
(0.085) \\
\end{array}$ \\
\hline \multicolumn{7}{|l|}{ Interaction effects } \\
\hline Absolute income $\mathrm{X}$ & & & $1.034 * *$ & $1.035^{* *}$ & $1.046^{* *}$ & 1.022 \\
\hline Middle Yitzhaki & & & $(0.011)$ & $(0.012)$ & $(0.015)$ & $(0.012)$ \\
\hline Absolute income $\mathrm{X}$ & & & $1.151 * * *$ & $1.145 * * *$ & $1.149 * * *$ & $1.111 * * *$ \\
\hline High Yitzhaki & & & $(0.025)$ & $(0.026)$ & $(0.031)$ & $(0.026)$ \\
\hline Absolute income $\mathrm{X}$ & & & & 0.905 & 0.866 & 0.922 \\
\hline One parent working & & & & $(0.062)$ & $(0.070)$ & $(0.064)$ \\
\hline Absolute income $\mathrm{X}$ & & & & 0.879 & 0.861 & 0.922 \\
\hline Two parents working & & & & $(0.064)$ & $(0.075)$ & $(0.068)$ \\
\hline Absolute income $\mathrm{X}$ & & & & $0.864 *$ & 0.879 & $0.874^{*}$ \\
\hline College & & & & $(0.056)$ & $(0.068)$ & $(0.058)$ \\
\hline Absolute income X & & & & $0.831 * *$ & 0.904 & $0.819 * * *$ \\
\hline School & & & & $(0.048)$ & $(0.062)$ & $(0.048)$ \\
\hline Absolute income $\mathrm{X}$ & & & & 0.990 & 0.960 & 0.966 \\
\hline No qualifications & & & & $(0.097)$ & $(0.111)$ & $(0.096)$ \\
\hline \multicolumn{7}{|l|}{ Goodness-of-fit } \\
\hline Log likelihood & 23,140 & 22,416 & 22,384 & 22,373 & $-31,497$ & $-23,179$ \\
\hline AIC & 46,310 & 44,864 & 44,804 & 44,792 & 63,040 & 46,404 \\
\hline
\end{tabular}

Note. ${ }^{*} \mathrm{p}<.05, * * \mathrm{p}<.01, * * * \mathrm{p}<.001$. AIC $=$ Akaike's Information Criterion 